Global Sustainability

cambridge.org/sus

\section{Review}

Cite this article: Crews TE, Carton W, Olsson L (2018). Is the future of agriculture perennial? Imperatives and opportunities to reinvent agriculture by shifting from annual monocultures to perennial polycultures. Global Sustainability 1, e11, 1-18. https:// doi.org/10.1017/sus.2018.11

Received: 28 January 2018

Revised: 11 September 2018

Accepted: 19 September 2018

Keywords:

agriculture; Earth systems (land, water and atmospheric); ecosystem services; land use; policies; politics and governance

Author for correspondence:

T. E. Crews, E-mail: crews@landinstitute.org

(c) The Author(s) 2018. This is an Open Access article, distributed under the terms of the Creative Commons AttributionNonCommercial-ShareAlike licence (http:// creativecommons.org/licenses/by-nc-sa/4.0/), which permits non-commercial re-use, distribution, and reproduction in any medium, provided the same Creative Commons licence is included and the original work is properly cited. The written permission of Cambridge University Press must be obtained for commercial re-use.

\section{CAMBRIDGE} UNIVERSITY PRESS

\title{
Is the future of agriculture perennial? Imperatives and opportunities to reinvent agriculture by shifting from annual monocultures to perennial polycultures
}

Timothy E. Crews ${ }^{1}$, Wim Carton ${ }^{2}$ and Lennart Olsson ${ }^{2}$ ${ }^{1}$ The Land Institute, Salina, Kansas, 67401, USA and ${ }^{2}$ Lund University Centre for Sustainability Studies (LUCSUS),
22100 Lund, Sweden

Non-technical summary. Modern agriculture is associated with numerous environmental predicaments, such as land degradation, water pollution, and greenhouse gas emission. Socio-economically, it is characterized by a treadmill of technological change, increased mechanization, and economic consolidation, while depressing economic returns to farmers. A root cause is the dominance of annual plants cultivated in monocultures. Annual crops require the yearly clearing of vegetation resulting in soil erosion and other forms of ecosystem degradation. Monocultures are susceptible to agricultural pests and weeds. By contrast, perennial polycultures informed by natural ecosystems, promise more sustainable agroecosystems with the potential to also revitalize the economic foundation of farming and hence rural societies.

Technical summary. Ten thousand years ago, humans begun domesticating wild annual plants to create the cereals and pulses that provide the mainstay of our food. The choice to domesticate annuals initiated the expansion of a novel and ecologically simple food-producing ecosystem, dependent on frequent and intense soil disturbances. Here we discuss the ecological, social and economic consequences of annual grain agriculture. In converting natural perennial ecosystems to annual crop monocultures for the provisioning of food, the ecosystems services of soil formation, nutrient retention, organic matter storage, pest suppression and others have been converted into the disservices of soil erosion, nutrient contamination, loss of organic carbon, and reliance on toxic agrochemicals. These processes are accelerated by increasing economic consolidation in agricultural industries and the relentless pursuit of economic efficiency, which has not only carried major consequences for the environment but also for the social fabric of rural societies. But a different agriculture is possible. We now have the technical capacity and ecological understanding to reinvent agriculture, so that it captures the key features of perenniality and diversity that characterize natural terrestrial ecosystems. Such a reinvention would also challenge the social and economic relations that uphold the current industrial model of agriculture.

\section{Introduction}

It is well-known that modern agriculture has far-reaching implications for sustainability. Despite being the foundation for life, the current state of agricultural soils and the ecosystems they are part of is one of degradation, depletion and pollution. Whereas natural ecosystems such as grasslands and forests provide taken-for-granted ecosystem services in the form of species diversity, soil protection, carbon storage and water purification, the frequent tillage of soils and a lack of vegetation cover for prolonged periods of time are associated with extensive soil erosion, soil carbon loss and nutrient runoff into ground and surface waters. These detrimental outcomes of row crop agriculture are increasingly characterized as forms of ecosystem disservices [1] that are the inevitable result of converting natural ecosystems to annual, monoculture croplands.

Agriculture's most fundamental problems can be traced back to its origins some 10,000 years ago, when humans began to replace diverse ecosystems dominated by perennial plants with simplified ecosystems that required frequent disturbance [2]. However, the rate of degradation and depletion has increased rapidly as a consequence of the intensive, mechanized and agrochemical-dependent farming practices of the past decades [3-5]. Though it would be wrong to characterize traditional agricultural systems as necessarily sustainable, they were, as Smil points out, fully renewable energetically in the sense that they were "powered by the photosynthetic conversion of solar radiation [which] produced food for people, feed for animals, recycled wastes for the replenishment of soil fertility, and fuels for smelting the metals 
needed to make simple farm tools" [6]. It was a thermodynamic necessity that more food calories were produced on farms than farmers invested in growing the food [7]. The rapid industrialization of Europe in the 19th and 20th century, fueled by coal and then oil, marked an abrupt end to this energy logic. It set in motion a steady transition from a solar to a fossil fuel economy $[6,8]$, that has fundamentally transformed agriculture. Today, humans have figured out how to address virtually every ecological limiting factor to crop growth - nutrients, water, insect herbivory, weed competition, disease - with fossil fuels [9]. Of the energy required to 'farm' a typical acre of maize in the USA today, $99.95 \%$ of the calories used originate from fossil fuels [9]. It is not uncommon today in industrialized cropping systems to expend four times the fossil fuel calories growing food such as tomatoes, than what the food itself contains [9].

It is hard to overstate the implications of this energy revolution for agriculture. As fossil fuels came to power agricultural processes, the interlinked social and ecological processes that had underpinned farming for thousands of years underwent dramatic changes. One gallon (3.79 1) of gasoline can deliver the 'work' energy equivalent of 100 hours of human labour, or approximately 2.5 weeks of work at eight hours per day [9]. The economics of this comparison help explain the extent to which fossil fuels have been substituted for human and animal labour in industrial agricultural systems. It also helps to explain the dramatic landscape changes that industrial farming has made possible, the increases in field sizes and concomitant reductions in hedgerows and biodiversity, the trend towards monoculture cropping and the consolidation of farms into ever fewer hands [10,11]. These combined social and ecological processes can be directly linked to the ecosystem disservices that we explore in more detail below. The energetic opportunities provided by fossil energy, together with the reduction in agroecological complexity and diversity that mechanization required, is one of the underlying drivers behind the rate at which natural ecosystems have been degraded and polluted, and topsoils have been lost.

A wide range of solutions have been tested in order to 'fix' the problems of industrial agriculture. In spite of the tremendous financial and human resources expended, however, the environmental challenges described above remain, and in some cases have become even more troublesome [12]. In response to this, a number of researchers have been exploring more radical solutions such as designing agroecosystems that more closely resemble the diverse natural ecosystems that preceded the cultivation of annual crops [13]. Here we specifically explore the research effort to mimic functional aspects of natural grasslands in the development of sustainable grain agroecosystems [14]. Two of the research areas deemed most critical to facilitate this are the breeding of perennial grain crops, and the management of higher diversity cropping arrangements. Naturally occurring plant communities, whether forests, prairies, deserts, savannahs, or tundra, are almost universally dominated by diverse perennial species. Perennials provide year-round soil coverage and large carbon inputs from roots and decaying plant material, two characteristics that are believed to be the foundation for many of the ecosystem functions that these plant communities provide. While aspects of a 'natural systems agriculture' are not new - indeed the cultivation of higher crop diversity including cover crops has been and remains common in some farming systems - it has been largely forgotten in industrialized agriculture as mechanization and chemical inputs made it possible and economically advantageous to grow large stands of individual crop species.
This article reviews the case for the development of diverse and perennial agroecological systems. It does this by following Erik Olin Wright's three-stepped framework for 'envisioning real utopias' [15], of which we think our focus here is a good example. Hence, we first formulate a theoretically informed and systematic critique of the existing agroecosystem by summarizing the most important ecosystem services that were sustained by ecosystems that preceded agriculture, and then explore how these services turned into disservices with the conversion of natural ecosystems to croplands. Secondly, we envision alternatives by discussing how a new agriculture, informed by the structure and function of natural grasslands, has the potential to resolve the tradeoff between the provisioning of food and other critical ecosystem services (Figure 1). Such alternatives must be desirable, viable, and achievable [16]. This section also gives a brief state-of-play of ongoing research in this field. Thirdly, we provide some thoughts on the process of transformation by elaborating the potential barriers to the envisioned alternative we propose, and how these can be overcome.

\section{The many problems of agriculture}

\subsection{Soil formation and erosion}

Soils are typically made up of approximately $1-10 \%$ organic matter (of which $\sim 58 \%$ is carbon), $50 \%$ mineral matter (sand, silt or clay), and the rest is pore space that is either occupied by water or air [17]. And while they constitute a small percentage of soil mass, the millions of species of bacteria, fungi, nematodes, earthworms, protozoa and other groups that make up the soil organismal community are increasingly recognized as key participants and in some cases primary drivers of ecosystem processes $[18,19]$. Soils form slowly from the vantage of a human lifetime, but there is variation in rates of formation depending on the climate, parent material (e.g. rock or sediment), topography and vegetation of particular geographic settings [20]. Montgomery estimated the net global median rate of soil formation to be $0.004 \mathrm{~mm}$ per year [21].

Perennial vegetation plays a key role in soil formation, as it protects against erosion throughout the year, and it allocates a considerable amount of carbon to roots, which subsequently contributes to the formation of soil organic matter (SOM) [22]. Almost all terrestrial or land-based ecosystems become dominated by perennial plants because once perennials are able to establish as seedlings, they have an inherent advantage over annual plants at the beginning of a growing season. Since annual plants have to re-start their growth cycle from a relatively small seed every year, they are vulnerable to being out-competed for sunlight or soil resources, such as water, by already established perennial plants that emerge quickly from dormancy at the end of winter, or a dry season [23]. Annuals only persist as the dominant vegetation type past a few years in ecosystems that experience frequent, extreme disturbance, such as annual flooding along large rivers, or landslides. There are a few exceptions in Mediterranean environments, such as the California grasslands in parts of the Sierra foothills that were converted from perennial to annual vegetation through livestock grazing and fire (such ecosystems still feature woody perennial species) [24]. These annual grasslands appear to have been losing organic matter steadily since conversion, representing a backwards trajectory in soil development [25].

Interestingly, perennials do not come to dominate ecosystems because they facilitate soil development - a process that happens 
Natural Ecosystem

Perennial-High Diversity
Agriculture

\section{Annual-Low Diversity Perennial-Moderate Diversity}

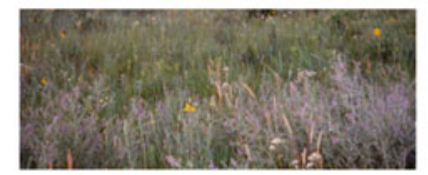

Ecosystem Services

Soil formation

Maximizes soil organic matter Resistant to pathogens and insects Nutrients retained

Weed establishment suppressed High functioning soil microbiome High precipitation use efficiency No fossil fuel dependence

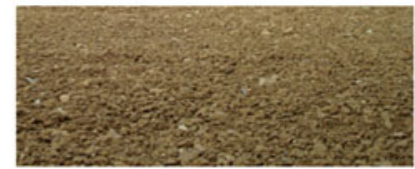

Ecosystem Dis-services

Soil erosion

Reduces soil organic matter Vulnerable to pathogens and insects Unintentional nutrient losses Weeds establish easily Low functioning soil microbiome Low precipitation use efficiency Heavy fossil fuel dependence

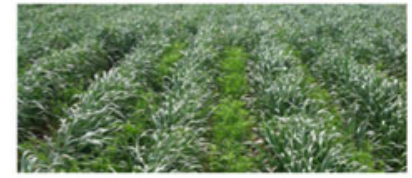

Ecosystem Services

Soil formation

Maximizes soil organic matter Resistant to pathogens and insects Regulated nutrient losses Weed establishment suppressed High functioning soil microbiome High precipitation use efficiency Reduced fossil fuel dependence

Fig. 1. The evolution of ecosystem services and disservices in agriculture [14].

over very long spans of time - but because they out-compete annuals [23]. And yet without perennials, it is arguable that soils would not develop in the first place, at least nothing close to the depth and organic enrichment of the soil profiles that exist today. Soil erosion can be viewed as an ecosystem disservice that replaced the ecosystem service of soil formation when croplands replaced grasslands and other natural ecosystems around the planet. When protective perennial vegetation is removed to make way for agriculture, the soil is exposed to wind, rain, and the effects of gravity for weeks and even months every year [26]. Soil is even vulnerable to erosion for weeks after a crop has been sowed, until the young crop canopy closes [27].

The degradation of soils is arguably the greatest ecosystem disservice that has resulted from the conversion of natural ecosystems to annual crop agriculture. In contrast to the $0.004 \mathrm{~mm}$ global median rate of soil formation, Montgomery estimated that the net global median rate of soil loss in tilled agriculture is $1.52 \mathrm{~mm}$ per year, and $0.065 \mathrm{~mm}$ per year in no-till agriculture [21]. These rates of soil loss are 360 and 16 times the rate of soil formation, respectively. It is evident that annual crops exploit rather than build on the soil capital that developed under the perennialdominated natural ecosystems that preceded agriculture.

The threats of soil erosion and land degradation have been a problem ever since the beginning of agriculture. Indeed, the Fertile Crescent, where wheat was first domesticated in Mesopotamia, has in many places been transformed by agriculture into a wasteland [26]. Soil degradation contributed to civilization decline in the Indus Valley, Greece, Italy, China and parts of Mesoamerica [26,28]. And the problem continues today. According to one calculation, 24 billion tons of soil are lost annually around the world - several tons for each person on the planet [28]. In 2015, a pan-European inventory of soil loss reported that farmland, managed forests and semi-natural areas were losing on average 2.5 tons of soil ha $\mathrm{hr}^{-1}$, while about 4 million ha of European cropland was losing more than
5 tons $\mathrm{ha}^{-1} \mathrm{yr}^{-1}$ [29]. Also in 2015, a team of 200 soil scientists from 60 countries working with the Food and Agriculture Organization (FAO) to assess the condition of soils around the globe concluded "while there is cause for optimism in some regions, the overwhelming conclusion from the regional assessments is that the majority of the world's soil resources are in only fair, poor or very poor condition. The most significant threats to soil function at the global scale are soil erosion, loss of soil organic carbon and nutrient imbalance. The current outlook is for this situation to worsen unless concerted actions are taken by individuals, the private sector, governments and international organizations" [30].

\subsection{Soil organic matter loss from tillage}

Soil erosion is the most destructive form of soil degradation that results from the conversion of natural ecosystems to croplands [31], but even when soil particles are not physically removed by wind or water, soils can lose a key component of what makes them productive: organic matter. SOM is an umbrella term for a wide range of substrates that form in the decomposition process of plants, animals and soil microbes [17]. SOM is not a static property of soil, but rather reflects a dynamic equilibrium between inputs of new organic compounds from plants, originating from photosynthesis, and losses of organic matter from soil microbes metabolizing organic matter and respiring $\mathrm{CO}_{2}$ to the atmosphere [2].

When ecosystems are converted to croplands, this dynamic equilibrium between organic matter inputs and losses is dramatically altered, resulting in substantial declines in overall SOM stocks [32]. Soil scientists recognize that plant roots represent the most important avenue by which new organic matter enters a soil profile [33]. Senesced plant parts such as leaves and wood that accumulate on the soil surface also contribute to SOM, but less of those materials persist by becoming incorporated into soil aggregates. Perennial grasses and forbs, such as those that 
make up native grasslands, allocate anywhere from $50-67 \%$ of fixed carbon in root or root-like tissues belowground [34]. In addition, most plants host networks of mycorrhizal fungi that act in some ways as filamentous root extensions, helping plants to explore larger soil volumes to scavenge nutrients, among other functions [35]. It is these combined processes that gradually build the dark surface or 'A' horizon that commonly characterizes grassland and forest soils (Figure 2) [36]. By contrast, annual species, including crops such as wheat, corn and sunflowers, allocate on the order of $15-30 \%$ of their productivity belowground [37]. The reduction in root-associated organic matter that occurs in the transition from perennial vegetation to annual crops is one reason why SOM declines with agriculture [22].

Another reason SOM declines is that outputs or losses of organic matter increase when natural ecosystems are converted to annual croplands. In undisturbed soils, organic matter is stabilized inside naturally forming soil clods or aggregates [38]. Soil scientists believe that this stabilization occurs in part because microbes have a difficult time accessing SOM when it is bound between slightly charged clay particles in the middle of aggregates [38]. A glue-like protein called glomalin, produced by mycorrhizal fungi, is also thought to play an important role in stabilizing soil aggregates [39]. When soils are plowed, mycorrhizal fungi are degraded, and the aggregates containing physically protected organic matter are broken open, exposing the SOM to microbial attack [38]. This enhancement of microbial activity happens every time a soil is tilled until $20-70 \%$ of the SOM accumulated under native vegetation has been lost, at which time a new reduced SOM steady state is established [32,40].

The conversion of tall, medium and short grass prairies to croplands that took place across the Great Plains, USA, at the turn of the 20th century by itself resulted in release of approximately $5 \mathrm{Pg}$ of carbon, similar to the emissions from deforestation in the Brazilian Amazon rainforest [41]. Sanderman et al. estimate that since humans first started farming, cropland soils globally have lost a total of approximately $35 \mathrm{Pg}$ of carbon to the atmosphere, with the rate of loss increasing dramatically in the last 200 years [5]. This value, which equates to approximately $3-4$ years of current anthropogenic $\mathrm{CO}_{2}$ emissions from fossil fuels and cement [42], is a defensible but high-end approximation of how much carbon cropland soils might ultimately re-accumulate over decades if perennial vegetation were re-established. Enhancing the uptake of carbon in vegetation and soils is increasingly promoted as a necessary (and low-cost) strategy to help mitigate climate change [43].

\subsection{How soil organisms respond to disturbance}

SOM consists mainly of plant and microbial tissues in various stages of decomposition, but typically $1-4 \%$ is made up of a living soil food web featuring bacteria, fungi, and other organisms that play a wide range of important ecosystem functions [44]. Advances in molecular techniques, such as DNA fingerprinting and next generation sequencing, have helped facilitate greater insight into the nature of microbial diversity in soils. However, ecologists are still in the early stages of being able to link many microbial taxa with specific functions [45]. Multiple studies have documented marked shifts in soil organismal communities when native ecosystems are converted to row crop agriculture [46-49]. These differences are attributed to several factors associated with agricultural conversion, including the quantity and quality of plant inputs and loss of SOM, the physical disturbance associated

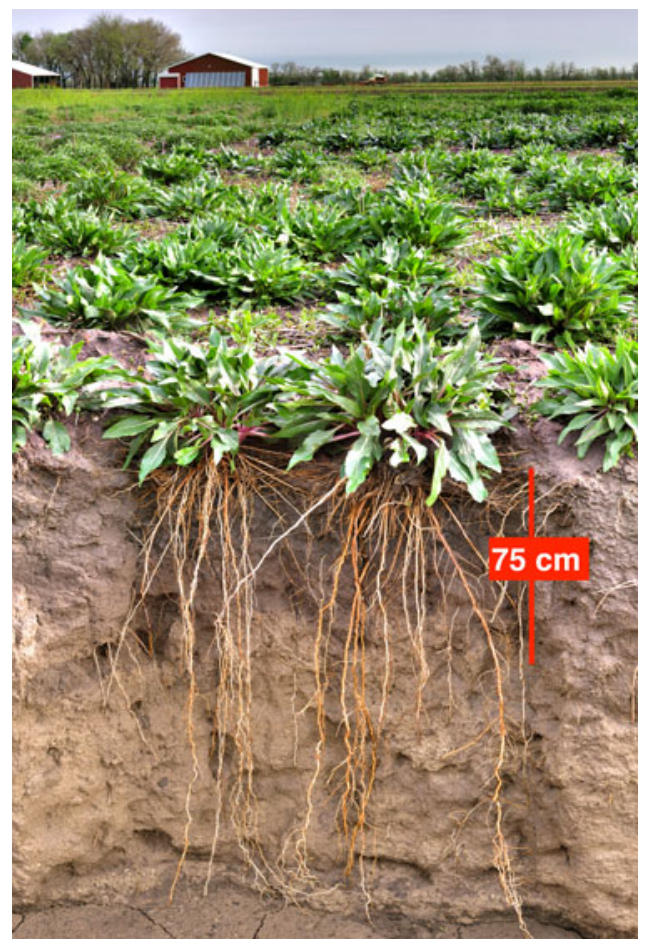

Fig. 2. Silphium integrifolium above and belowground. This native prairie species of the Great Plains USA is undergoing domestication as an oilseed crop. The organic matter enriched A horizon of the Mollisol soil is evident to a depth of $75 \mathrm{~cm}$ (Photo: Steve Renich).

with tillage, and alterations of resources such as nitrogen, phosphorus and water. While these changes unambiguously impact the soil food web, the functional implications of these community differences are just beginning to be appreciated. For example, comparing soil nematode communities under annual crop rotations with those of intact native grasslands, Culman and colleagues found significantly greater parasitic trophic groups in the agroecosystem, and greater $\mathrm{N}$-mineralizing plant associate groups in the grassland [47].

Mycorrhizal fungi are a noteworthy category of soil organisms that are clearly affected by ecosystem conversion to agriculture [50]. Mycorrhizae form symbiotic relationships with most species of plants, and are often important, if not essential, for increasing nutrient availability, suppressing plant diseases, and building SOM [35]. Recent work sheds light on endophytic mycorrhizae having very different growth-promoting effects depending on successional status of the plant community being colonized [51]. For example, in studies of prairie species in central USA, Koziol and colleagues found that perennial plants that dominate mature, later successional communities, exhibit much greater growth responses to mycorrhizal fungi than perennials that establish in recently disturbed soils [52].

\subsection{Is chemical weed control a viable practice?}

In the last 50 years, agronomists have devised ways to substitute chemical control of weeds for the traditional mechanical controls of plowing and disking. 'No-till' cropping involves carefully timed applications of herbicides to kill vegetation so that the soil remains intact with crop residues remaining on the surface [53]. The development and release of herbicide-tolerant crops in recent 
decades has helped to increase adoption of these practices, especially in North and South America, and Australia [54]. By eliminating tillage, farmers not only greatly reduce erosion, but they also address one of the two ways in which the ecosystem disservice of SOM decline occurs [22]. No-till does not enhance microbial consumption of SOM, and thus many have suggested that some fraction of the carbon that was lost following initial cultivation should be recaptured once no-till practices are adopted [55]. Interestingly, evidence for such re-accumulation of SOM is equivocal, leading to strong disagreements in the academic literature regarding the role of no-till in rebuilding SOM [56].

With respect to soil health and protection, no-till cropping systems, especially when expanded to include diverse cover crops between plantings of commercial crops, may be the most sustainable way of raising grains at the present time. However, the method depends on applications of herbicides, which carry a range of human health and ecosystem hazards. In 2014, the World Health Organization released a study suggesting that the most commonly used herbicide in the world - glyphosate - is a potential carcinogen [57]. The findings were refuted by industry groups primarily based on results from the American Agricultural Health Study, even though the study noted that there was some evidence of increased risk among the highest exposed group [58,59]. While the issue has been debated back and forth in the scientific literature with contradictory conclusions, a cautious approach seems advisable [60]. Even if most studies suggest that herbicide impacts on soil function are minor and/or temporary [61], there are concerns about the inhibition of soil nitrogen cycling [62], disruptions to earthworm ecology [63], and damage to mycorrhizae [64], and other soil micro-organisms [65]. Moreover, where it is widely used, the efficacy of glyphosate has declined as resistance to the herbicide has developed in over 40 weed species [66]. This has compelled the herbicide industry to develop crops that are tolerant of herbicide cocktails, which are expected to carry greater health risks than singular glyphosate applications [67] and further exacerbate resistance [68]. From a socio-economic point of view, the widespread use of pesticides may not improve the economic viability of farming (discussed further in Section 4).

\subsection{Nutrient retention and loss}

We have made the case thus far that natural ecosystems build soils, which includes SOM, whereas annual croplands commonly degrade or lose soils. More difficult to observe, but no less important is the well-developed capacity for natural ecosystems to retain critical nutrients for plant growth, and the tendency for annual croplands to lose them. In 1975, ecologists Peter Vitousek and William Reiners published what is now a classic paper in ecology titled 'Ecosystem succession and nutrient retention: a hypothesis' [69]. In this paper, the authors explain how highly disturbed ecosystems are predicted to leak prodigious quantities of nutrients, but when these same ecosystems are allowed to undergo ecosystem development over the course of succession, nutrients become much more highly regulated and tightly retained, resulting in very low leakage to adjacent lands, rivers or lakes. While Vitousek and Reiners were describing the effects of extreme natural disturbances such as landslides or catastrophic fires or floods, their model describes precisely what happens to ecosystem nutrient retention in annual croplands that are disturbed by tillage. Some have suggested that the annual grain crop ecosystem is the most disturbed ecosystem on the planet when areal extent, frequency and intensity of disturbance are considered together [2].

When natural ecosystems are converted to croplands, the ecosystem service of nutrient retention gives way to the disservice of nutrient loss and related excessive freshwater or marine algae growth, or eutrophication. Nitrogen and phosphorus commonly interact to control how much algae grows in lakes and rivers [70]. Phosphorus does not tend to move easily in soils, but it is commonly lost from landscapes via surface runoff [71]. Nitrogen, on the other hand, is readily carried in the form of nitrate in water that leaches through soils ultimately flowing into rivers and lakes [36]. Freshwater eutrophication does happen naturally in certain situations, but it has become extremely common, even the norm, for lakes and rivers in heavily fertilized agricultural regions to become eutrophic for extended periods in most summers [72].

Nitrogen, in the form of nitrate, not only plays a damaging role in stimulating algae growth in rivers and lakes, but also in coastal marine ecosystems. For example, in the Gulf of Mexico, a large dead zone forms every summer as a consequence of the Mississippi river delivering nitrate from upstream point and nonpoint sources $[73,74]$. The most important of these sources is fertilized agricultural fields that cannot retain nitrate because soils are left with few or no active roots for a majority of every year [75]. Productivity of algae increases in response to the added nutrients and then decomposition of dead algae also increases [74]. The organisms that decompose the algae consume the oxygen in the water, which causes other oxygen-breathing organisms (such as fish) to die [74]. There are more than 400 dead zones around the world with fertilizer loss being the most important driver [76].

\subsection{Water infiltration and use}

The capacity for native perennial ecosystems to retain nutrients in general and nitrate in particular is linked in part to their capacity to take up soil water in which the nutrients are dissolved [77]. Relative to row crop agriculture, natural ecosystems characteristically transpire a higher percentage of the precipitation they receive. Generally, this is attributable to high soil infiltration rates and soil water storage capacities, and greater recovery of stored water [78]. High infiltration occurs because aggregates and associated large pore spaces are able to develop in soils that go undisturbed though activities of soil fauna such as earthworms, and generations of root growth and die-back. Once infiltrated, soils can store large volumes of water. Deeply rooted perennial species have been shown to recover water deep in the soil profiles, in some cases up to several meters [79].

When natural ecosystems are converted to agriculture, the ensuing soil disturbance can drastically alter the hydrological flows in the ecosystem. Tillage can initially improve water infiltration rates, but in silt or clay-dominated soils, the destruction of soil aggregates and macro-pores results in compromised infiltration [80]. When water is prevented from infiltrating, it runs off, carrying dissolved nutrients and particulate matter. The absence of vegetation covering soils for long durations only exacerbates the potential for serious runoff events. But even in cases where runoff is limited, lack of plant cover translates into much greater evaporative losses than occurred under perennial cover. Major disruption of hydrological flows with annual agriculture was illustrated by Rockstrom [81] in a study that traced the fate of rainfall in what were considered water-limited dryland cropping systems 


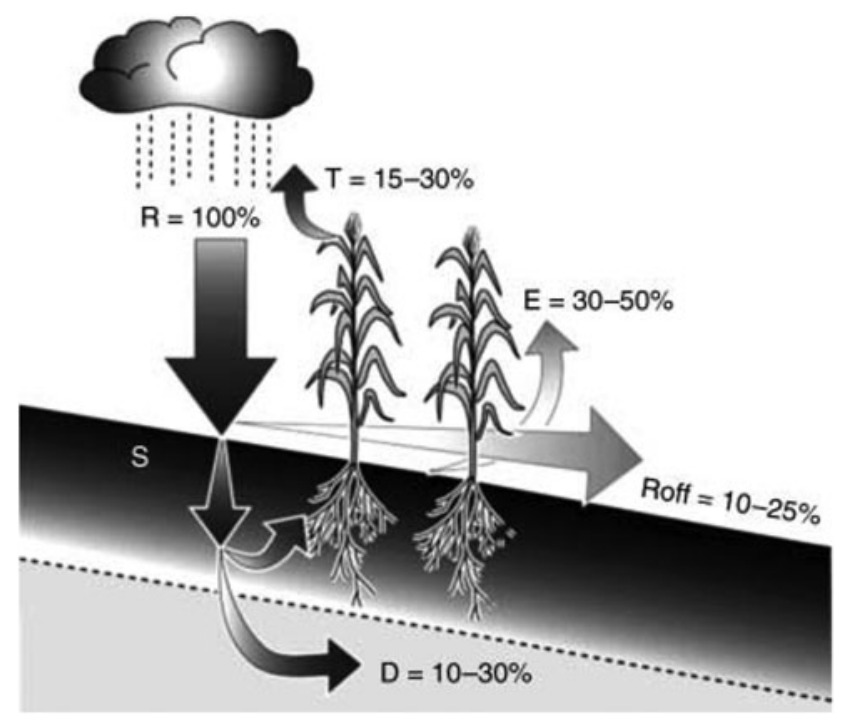

Fig. 3. The fate of rainfall in sub-Saharan maize cropping systems. D, deep leaching; $E$, evaporation; R, rainfall; Roff, soil surface runoff; S, Infiltration (defined as R-(Roff + E)); T, transpiration. Adapted from Falkenmark and Rockstrom [82].

in sub-Saharan Africa. He found that only $15-30 \%$ of precipitation was actually transpired by maize, with the remaining $70-$ $85 \%$ leaving the agroecosystem via surface evaporation, runoff or leaching below the rooting zone (Figure 3)

In addition to disrupting hydrological flows, the conversion of natural ecosystems to row crop agriculture diminishes the capacity of soils to store and supply water to vegetation in two other ways: loss of SOM and loss of soil itself. As we described earlier, soils predictably lose between $20-70 \%$ of SOM in the decades following initial tillage. The capacity of soils to soak up and hold water is strongly influenced by organic matter contents $[83,84]$. Thus, for example, a silt-loam soil with $1 \%$ organic matter only holds about half of the water for future plant uptake compared to the same soil with $6 \%$ organic matter [83]. In the long run, the fact that mineral and organic components of soil are commonly eroded much faster than they are formed under annual crop cultivation, underscores the risk of permanent water storage reductions with agriculture.

\subsection{Loss of biodiversity}

In recent decades, consensus has grown around how biodiversity contributes to important ecosystem functions which undergird valued ecosystem services [85]. Generally speaking, more diverse ecosystems have been found to be more productive and stable $[86,87]$. There are many reasons for this relationship. A plant community with high species richness is more likely to also contain higher functional diversity, that is, groups of species with specific roles in the community [85,88] such as biological nitrogen fixation [89], or the ability to bring water from deep in a soil to the soil surface through hydraulic lift [90]. Diverse plant communities are more able to fully utilize biologically essential resources such as water, sunlight and nutrients because different plant species tend to have different resource requirements [86,91]. More diverse communities are also more likely to contain highly productive species. Why is it then that ecosystems are not commonly dominated by one or two highly productive species? In part, it is because the competitiveness of individual species varies with

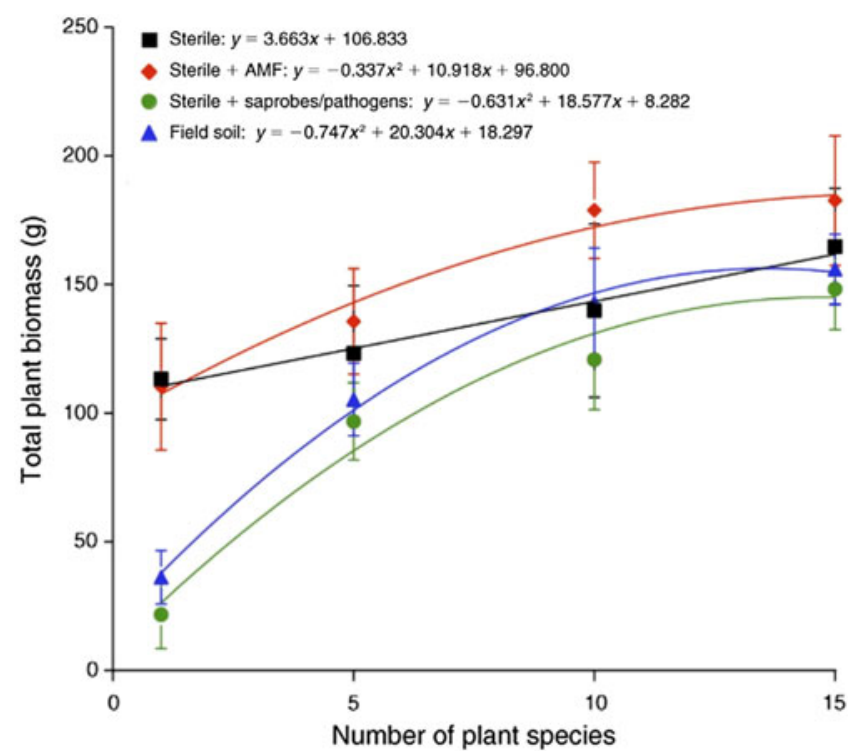

Fig. 4. Experimental results by Schnitzer and colleagues [94] showing how plant community productivity increases with greater diversity through the suppression of soil pathogens. Design involved large pots filled with field or sterilized soils. The sterile soil treatments included no inoculums (black), mycorrhizal fungi inoculum (AMF) (red) or disease-containing inoculum (green).

changing environmental conditions. Another explanation is that over time plant communities with low diversity tend to succumb to pathogens [92].

Diversity of plant species in ecosystems is thought by some to reflect historic pathogen pressures causing a few dominant, productive species to lose their competitive edge, thus allowing for colonization by other species [92]. Once established, diverse plant communities can function to regulate and suppress widespread epidemics of pathogens $[86,93]$. The ecosystem service of plant diversity suppressing soil pathogens is illustrated in an experiment by Schnitzer and colleagues (Figure 4) involving large pots filled with four soil treatments (direct from field, sterilized, sterilized + pathogens, and sterilized + beneficial fungi) and planted with one, five, ten or 15 different plant species [94]. When grown as single species, plants in sterilized soils achieved significantly greater productivity than plants grown in field soils or sterilized soils with pathogens added. This suggests that under conditions of low plant diversity, pathogens can have a large negative impact on productivity. However, pathogen suppression of plant growth declined as species diversity increased to where at maximum diversity, there was no pathogen suppression evident [94]. This result illustrates the possibility of reducing disease pressure on agricultural crops not through the application of toxic fungicides, but rather through the deployment of greater crop diversity.

Before the advent of industrialized agriculture, it was typical for farmers around the world to grow a high diversity of crop species, often in polycultures [95]. The agricultural biodiversity they maintained was usually much lower than the species richness of the natural ecosystem agriculture replaced, but nevertheless polycultures and rotations were the norm [96]. Crop diversity often consisted of several primary crops (such as the classic Mesoamerican corn, bean, squash polyculture), along with a multitude of minor crops planted in break-rows or gaps in fields [97]. Crop diversity was deployed in either time (rotations) or 
space (intercropping) and was maintained in part because of local demand for diverse foods that were only produced locally. Diversity was also maintained as a primary tool to control disease and insect pests, as there were few chemical or biological options for pre-industrial farmers [7,97]. There have been numerous hypotheses proposed to explain why diversity may in some cases help regulate the reproduction and spread of pest organisms in natural and agricultural ecosystems. Three of those classic hypotheses are still widely considered today:

- Enemies hypothesis: vascular plant communities with higher diversity are more likely to provide continuous food and habitat resources that can sustain insect predator and parasitoid populations [98].

- Diversity-disease hypothesis: transmission rates of diseases are proportional to the abundance of the host. If higher plant richness leads to lower abundances of most plant species, then disease severity would decrease accordingly [99].

- Resource-concentration hypothesis: a disease or insect's success in establishing and spreading is proportionate to the patch size of the resource (e.g. crop plant) in time and space [100].

As agriculture industrialized in the twentieth century, the diversity of crops grown decreased at the field, farm and regional scales [101]. Mechanization favoured simple single-species cropping arrangements, and farmers shifted to relying on crops bred for resistance and on synthetic pesticides over diversity for crop protection [1]. Rotations with nitrogen fixing legume crops were replaced with continuous production of grains fertilized with nitrogen produced by the Haber-Bosch industrial synthesis of ammonia [102]. It is surprising to note that the increased use of pesticides since 1960 did not result in a corresponding decrease in crop losses to insect pests [103]. Indeed, Pimentel and colleagues reported that in spite of a ten-fold increase in insecticide use in the US between 1945 and 1989, the share of crop yield in the US lost to insects nearly doubled from 7 to $13 \%$ [104]. Recent studies on systemic pesticides confirm the limited benefit to farmers $[105,106]$ and thereby further put in question the economic rationale for widespread pesticide application [107,108].

The substitution of crop diversity by chemicals to suppress agricultural pests resulted in what may be the most publicly acknowledged ecosystem disservice of industrial agriculture pesticide poisonings. Most famously, Rachel Carson in her book 'Silent spring' chronicled how insecticides such as DDT could bioaccumulate through the food chain, resulting in health concerns and ecosystem impacts [109]. Many mark the birth of the environmental movement with the publication of Carson's book [110].

Over the decades, the agrochemical industry has responded to public concerns by developing toxins that better target the pest species and do not persist as long in the environment [111]. However, the recent controversy around neonicotinoid insecticides and their effects on pollinators demonstrate how even with careful testing, the widespread application of toxins can easily lead to unpredictable and unacceptable ecosystem impacts $[108,112,113]$. The extent of this ongoing problem might be severely underestimated. A study by Hallmann et al. describes an alarming $75 \%$ decline in flying insect biomass over a 27 -year period in selected protected areas in Germany [114]. While the causes of this remain unclear, the authors note that the combined processes of habitat loss and widespread pesticide use due to agricultural intensification are prime suspects. As with herbicides such as glyphosate, there are also concerns about the human health implications of insecticide use. Farmworkers and rural residents in particular are frequently exposed to dangerous levels of toxins [115]. Exposure can be especially problematic in less developed countries where warnings on imported pesticides may not be in the local language or regulations may not be enforced [116].

\section{Perennial grain agriculture, a radical alternative?}

We have so far summarized the different services that natural ecosystems provide and the disservices that arise when these ecosystems are converted to industrially cultivated croplands. In essence, this suggests that the current agricultural model delivers a problematic tradeoff between sustenance and sustainability that seems difficult to overcome within the predominant agricultural logic. In response to this, a number of researchers have suggested that natural ecosystems provide the best standard for evaluating the sustainability of agricultural ecosystems, and consequently also the best models for improving them (Figure 1). Specifically they have proposed that a more sustainable agricultural system will need to consist of mostly perennial species, and will need to be more diverse than is the case with present agroecosystems [2]. One of the most influential and charismatic voices in this debate is Wes Jackson, who in his 1980 book 'New roots for agriculture' proposed the creation of a new agriculture that is modelled after the prairie. By breeding perennial grain crops, including cereals, pulses and oilseeds, and by planting them in complementary arrangements, Jackson proposed that agriculture could be transformed from a soil degrading to a soil building activity [31]. This idea was by many considered utopian at that time, but continued research at The Land Institute in Salina, Kansas, since Jackson's book, has shown that it is achievable and similar research is now undertaken at many universities and research institutions around the world (Figure 5).

One of the greatest impediments to this vision, of course, is the lack of perennial grain crops. Almost all cereals and legumes consumed today are annuals, as are many oilseed crops such as soy, canola and sunflower. The reasons for this are several and partly have to do with the nature and limitations of the Neolithic plant domestication process [117]. Today however, given the robust plant breeding theory and methodologies developed over the last century, and recent leaps in molecular analyses, genomics and bioinformatics to help guide the breeding process, the idea of re-inventing or converting crops to be perennial is within reach. Based on progress that has been achieved in recent years on several perennial proto-crops, this is likely a matter of decades as opposed to the centuries that were required to create our current annual food crops. Researchers have for example had considerable success with the development of the new perennial wheat relative Kernza ${ }^{\oplus}$, which is domesticated from the wild perennial wheatgrass (Thinopyrum intermedium), and the sunflower relative Silphium integrifolium $[118,119]$. These two crops are being developed by Land Institute researchers along with colleagues at numerous other institutions [120]. In addition, researchers are also pursuing crosses between existing annual grains with a wild perennial relative. When successful, after generations of selection and inter-mating, these 'wide hybrid crosses' produce plants that maintain seed yield and quality similar to the annual parent while inheriting the perennial lifestyle from the other parent [121]. Examples of perennial crops at different stages in the wide hybridization pipeline include wheat, sorghum, rice and barley [118].

The idea that agriculture needs to be more perennial is a dramatic departure from the way humans have grown most of their 


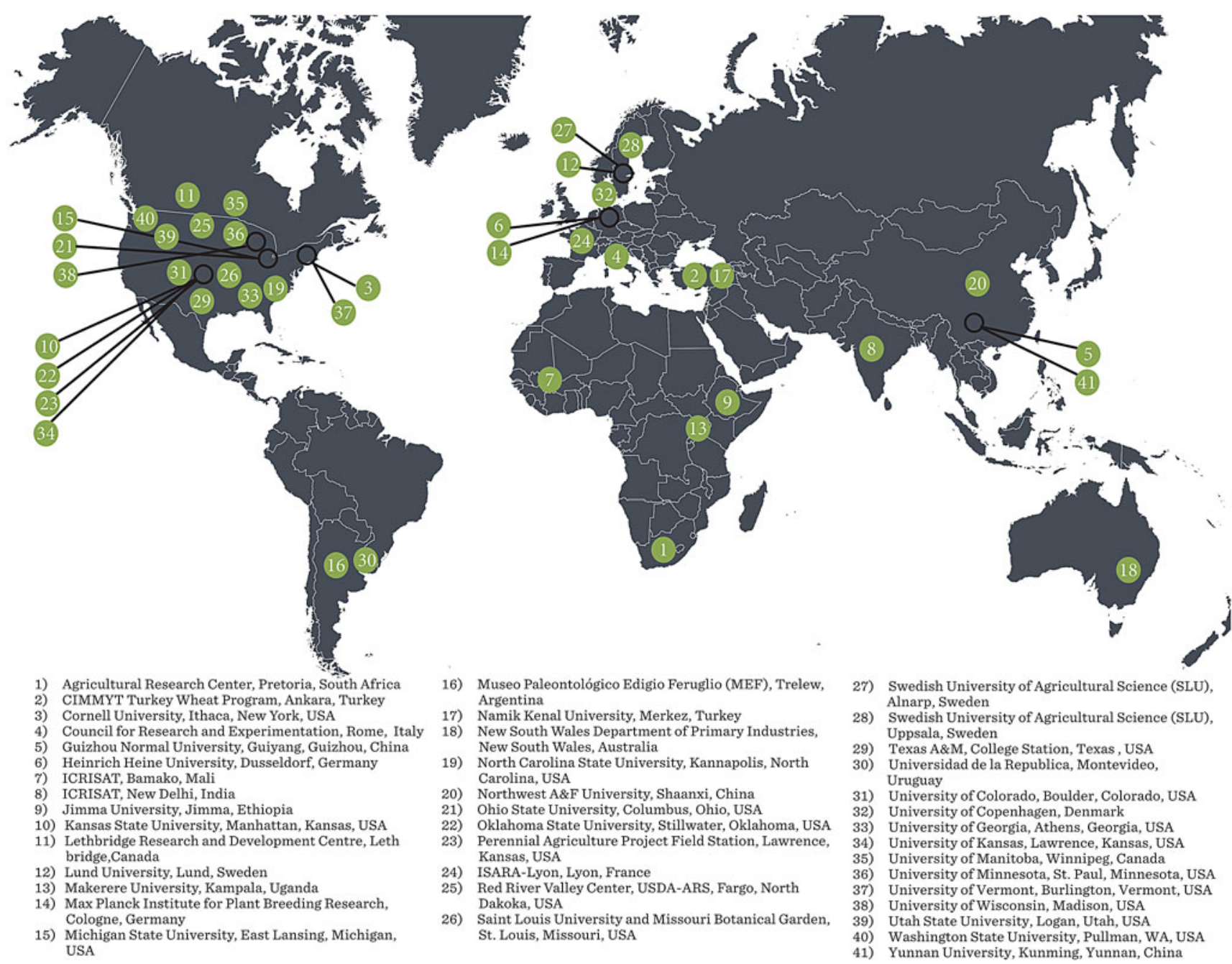

Fig. 5. Institutions around the world working to develop diverse, perennial grain agroecosystems [14].

cereal, oilseed, pulse and fibre crops in the last 10,000 years. And yet, as the previous section shows, the potential benefits for SOM accumulation, the prevention of soil erosion and nutrient leakage, water retention and biodiversity are well documented. As with natural ecosystems, perennial crops promise to accumulate higher levels of SOM than annual systems because they allocate comparatively more of their productivity to root growth [34]. But SOM accumulation does not happen quickly and is methodologically difficult to measure. In one study, researchers who attempted to measure increases in SOM under the perennial grain Kernza could not detect significant differences after four years since crop establishment [122]. In another study, researchers measured the carbon balance of a Kernza field over five years using eddy covariance observations and found an average net ecosystem carbon accumulation of $3.7 \mathrm{t} \mathrm{ha}^{-1} \mathrm{yr}^{-1}$ [123]. These values include the Kernza plant biomass; a fraction of which will be converted to stable SOM. In addition to these shorter-term studies, a growing literature documents SOM accumulation rates on lands that have been converted from annual cropping to perennial grasslands or perennial cellulosic biofuel crops. These studies suggest soil carbon accumulation rates of $0.33-1.88 \mathrm{tha}^{-1} \mathrm{yr}^{-1}$ [22]. These rates of soil carbon increase have been found to persist for one or two decades, and then gradually decline until no net carbon is sequestered after
50 years [22]. The wide range of soil carbon sequestration values reflects site-specific differences in soil texture, climate, vegetation composition, and degree of soil degradation experienced under agricultural management [17].

Compared to annual grains, perennials are expected to have lower water productivity, that is they will require more water per unit food produced because they transpire over a longer growing season and allocate less of their total photosynthate to seed [124]. However, as described earlier with reference to perennial grasslands, lower water productivity in perennial grains may be balanced by greater capture and utilization of total precipitation compared to annual cropping systems $[78,79,82]$. Moreover, continued improvement of seed allocation (or harvest index) through breeding will also improve on water productivity.

Intact perennial grasslands, which inform the design of perennial grain agroecosystems, are also extremely efficient at taking up nutrients such as nitrogen from both shallow and profound soil depths over a long growing season, which in temperate areas begins early in the spring and ends late in the fall [125-127]. This is partly explained by the uptake efficiency of perennial roots, and partly by the niche complementarity of diverse plant communities. Studies of nitrogen retention in diverse natural ecosystems and planted diversity experiments have found that plant 
communities that include different and complementary functional groups, will take up different forms of nitrogen from the soil profile at different times of the growing season $[86,128]$. Consistent with nutrient uptake patterns they also experience very low nutrient losses either via surface runoff or leaching through the soil profile [125-127]. This high degree of nutrient retention is one reason why grasslands can maintain high levels of productivity with very low nutrient inputs [129]. Even when grasslands experience the natural disturbances of fire or grazing, perennial plants re-grow with minimal disruption to nutrient uptake patterns [129]. Overall, water that leaves natural perennial grasslands is remarkably clean and free of nutrients [125-127]. Culman and colleagues at Michigan State University have confirmed that the same is true for at least one perennial grain crop. They compared the nitrogen retention of single species plantings of annual wheat and perennial wheatgrass or Kernza and found that once established, the perennial grain crop reduced total nitrate leaching by $86 \%$ compared to annual wheat [130]. The different uptake efficiencies of perennial wheatgrass compared to wheat make sense when the rooting systems of these two species are compared, as in Figure 6.

The other feature of natural ecosystems that many agree will improve agriculture is diversity. The idea of growing multiple crops species in close proximity is not new to agriculture, but has been largely forgotten in industrialized countries over the last century as mechanization and chemical inputs have made it possible and economically advantageous to grow large stands of individual crops. As our discussion above shows, greater crop diversity - both in species and varieties - are necessary at field, farm, and regional scales to eliminate dependence on synthetic pesticides and the ecosystem disservices they deliver [131]. Inter and intra specific diversity can play a critical role in helping to keep pest insects and diseases in check, and enhance productivity because resources such as sunlight, water, and nutrients are used more efficiently when species with different resource requirements grow together.

But the question of how much diversity and of what type is salient in the design of a resilient natural systems agriculture. A significant difference between annual and perennial cropping systems is that disease and insect cycles can be disrupted in the former by deploying diversity through rotations [132]. When a farmer replaces wheat with canola in a rotation, the populations of pest organisms that favour wheat are reduced [133]. Since it is not possible to disrupt a pest organism by removing its host in a perennial system, diversity needs to be deployed both within fields and across broader landscapes. For example, the deployment of varietal diversity can help maintain the efficacy of natural or introduced pest resistance genes [134]. Zhu found in the Yunnan Province of China that when a susceptible rice strain was grown in diverse mixtures with more resistant varieties of the same species, the proportion of plants affected by the panicle blast fungus (Magnaporthe grisea) was reduced to 1.2\% compared to $20 \%$ in a single variety monoculture [135]. The work of designing polycultures will never be complete as pest organisms are always evolving to overcome barriers that restrict their reproductive success, but diversity can potentially slow down evolution to a manageable rate. With carefully designed polyculture systems, agriculture should be able to capture the benefits of diversity seen in nature (Figure 7).

The modeling of agriculture on diverse, perennial ecosystems also has potential climate benefits. Industrial agriculture and the production of agricultural inputs are important sources of greenhouse gas emissions, both in terms of $\mathrm{CO}_{2}$ from fossil fuel combustion, and non- $\mathrm{CO}_{2}$ emissions from, for example, agricultural soils (nitrous oxide) or enteric fermentation in livestock farming (methane). These various emission sources are together responsible for approximately $11-13 \%$ of global greenhouse gas emissions [136]. Agricultural systems that more closely resemble natural ecosystems would be expected to decrease the greenhouse gas emissions of industrial agriculture by reducing the need for tilling hence the need for heavy machinery and energy inputs, and by replacing energy-expensive inputs such as synthetic nitrogen fertilizers with ecological processes such as biological nitrogen fixation $[137,138]$.

Moreover, perennial crops could confer significant adaptation benefits in the face of a more unpredictable and extreme climate as well. Climate change is set to bring new pests and diseases, increased flooding, droughts and heat waves, all of which may impact yields and profits [139]. Major staple crops including wheat, maize and rice will be damaged by climate change [140-142]. Already now, at $1{ }^{\circ} \mathrm{C}$ of warming, global wheat yields are estimated to have declined by 4.1 to $6.4 \%$ [141]. A transition to staple crops that are more effective users of nutrients and water and therefore potentially more resilient in the face of extreme weather makes a lot of sense in this context.

\section{Challenges and barriers to the transition}

Progress towards diverse perennial agricultural systems holds significant potential to move agricultural practices from a system that delivers an unsustainable set of ecosystem disservices, to one that delivers many of the essential services that natural ecosystems provide. What, then, does it take to achieve this radical vision for the future of agriculture? To round off our review we briefly consider the various challenges that need to be overcome, the future research that is required, and the potential tradeoffs and shortcomings of perennial systems that might interfere with their adoption. While our discussion here is by no means exhaustive, we hope it lays out some useful ideas for future research.

Some of the more immediate challenges have to do with continued advances in plant breeding. While a natural systemsinspired agriculture based on diverse perennial grains promises improvement in delivering many ecosystem services, unless it also delivers the provisioning ecosystem service of adequate food production currently provided by annual grains to meet humanity's needs, this new agricultural model will likely be confined to a niche market. Modern annual grains were developed over thousands of years, first through selection by farmers (mass selection), and in the last century through intensive scientific breeding methods (e.g. synthetic line production) [143,144].

In contrast to the long history of breeding annual grains, the process of breeding perennial grain species has only just begun. From a theoretical point of view, it has been argued that perennial grasses cannot be domesticated because they do not allocate sufficient energy for the development of large seeds [117,145]. While trade-offs do exist in allocation patterns of agricultural plant species, experience in modern plant breeding has demonstrated repeatedly that negatively correlated traits such as seed yield and longevity can be improved simultaneously through artificial selection [146-148]. An arguably more serious barrier is that domestication and breeding of perennial grains is at odds with the interest of the private seed industry, and there has been a dramatic shift from public to private plant breeding since the $1980 \mathrm{~s}$ [149]. As an illustration of this shift in the USA, from 1990-1994 there was a decrease of 2.5 scientists per year in public plant 
Fig. 6. Deep rooted intermediate wheatgrass (Thinopyrum intermedium) that produces the grain Kernza (left) and shallow rooted annual wheat (Triticum aestivum) on the right. This soil profile that was excavated at The Land Institute was approximately 2.5 m deep (Photo: Jim Richardson).

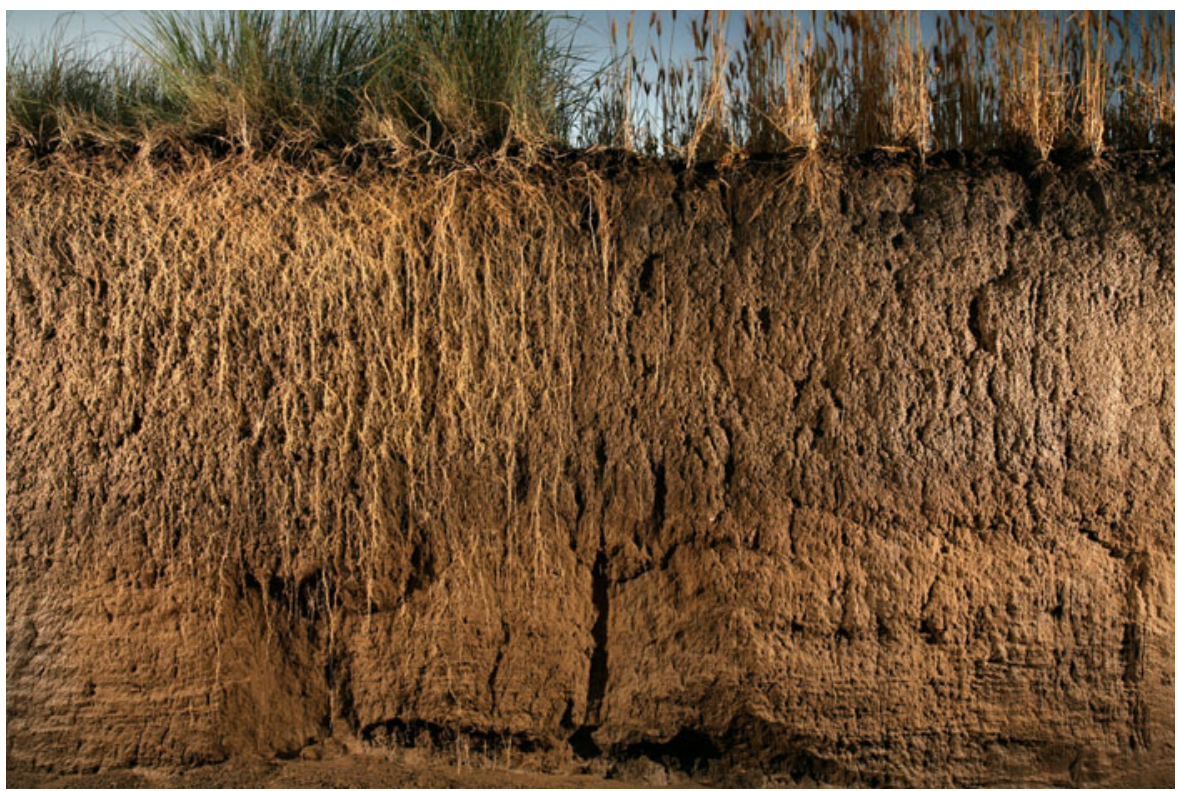

breeding while there was an increase of 32 scientists per year during the same period in private plant breeding [150].

Work on breeding perennial wheat by hybridizing annual wheat with a related perennial was initiated in multiple countries in the 20th century, but progress was slow and projects were often suspended for periods of time [151]. Multiple new perennial grain breeding initiatives have been launched since 1990 [120], and today, greater momentum exists in perennial grain development than ever before. Part of the recent momentum can be attributed to the expansion of the modern plant breeder's toolkit using advancements in molecular biology and genomics [152]. For the first time, it is technologically feasible and financially affordable to utilize information from plant DNA to complement the measurement of physical traits such as seed yield or shattering to accelerate breeding progress (e.g. [153]). To our knowledge, no research groups have in the past or are currently working to achieve perennialism in a grain crop using transgenic technologies, however molecular tools are proving to be extremely useful to improve the efficacy of traditional plant breeding methods [152]. Even with advances in plant breeding however, it will take decades of consistent effort to create crops that approach the yields per hectare provided by existing elite annual crops. And yet, as has been shown with almost every human technological advancement, progress is to a certain extent proportional to the financial and human resources dedicated to the challenge. Significant yield improvements in perennial grains such as Kernza are entirely feasible, and ongoing work towards that goal would be significantly advanced by making this research agenda a political and scientific priority. In the absence of interest from commercial plant breeders, perennial grain development will need to rely on alternative sources of funding and be innovative in the pursuit of low-budget approaches. Participatory Plant Breeding (PPB) could in this context provide a useful complement to the efforts of professional breeders [154-157]. Long-term experience (30 years) from Portugal show that farmer selection can be as effective as breeder selection in developing particular traits of maize [158].

Secondly, our review highlights the indisputable importance of ecosystem diversity. But how much diversity is needed to achieve the ecosystem services provided by grasslands, forests or savannas? A perennial system based on monoculture (or even intercropped) fields of Kernza is clearly less diverse than almost all natural ecosystems. Ecologists are in general agreement that functional group diversity is a better metric than species diversity in explaining diversity effects on productivity $[159,160]$. For example, in analyzing why more diverse plots at Cedar Creek biodiversity experiment in Minnesota achieved higher productivity, DeHaan and colleagues found that the higher diversity plots were more likely to contain legumes in general, and one legume in particular (Trifolium pretense). In other words, the presence or absence of legumes, not species richness, explained variation in productivity [89]. However, a natural systems-inspired agriculture as described in this paper will need to achieve more than productivity to be sustainable. A simple two species intercrop covering large landscapes will predictably succumb to insect and disease pressure, and may not fully utilize the resources of nutrients, water and sunlight. As perennial proto-crops move through the breeding pipeline, ecologists can begin experimenting with the 'works in progress' to get a head start on determining how much crop diversity is appropriate for a given region, and in what landscape configurations diversity should be deployed. How much wild diversity should exist in agricultural regions? While just an initial step, early work with the Kernza-lucerne bi-culture will enrich our understanding of how perennial crop species interact over years, and how changes in soil physical and biological properties feedback to influence long-term ecosystem productivity [2].

Thirdly, and no less importantly, the challenges in bringing about the perennial vision we have outlined here are also profoundly social, economic and political. How agriculture is organized and governed is highly consequential for the relation it maintains to the natural environment and its sustainability more generally. The far-reaching environmental impacts of the current agricultural model, for example, are directly linked to profound transformations over the past decades in how farming is practiced. William Cochrane in this context speaks of an 'agricultural treadmill' to refer to a self-reinforcing cycle of technological change, which increases the efficiency of agricultural inputs and machinery and suppresses food prices (and farmer income), in 


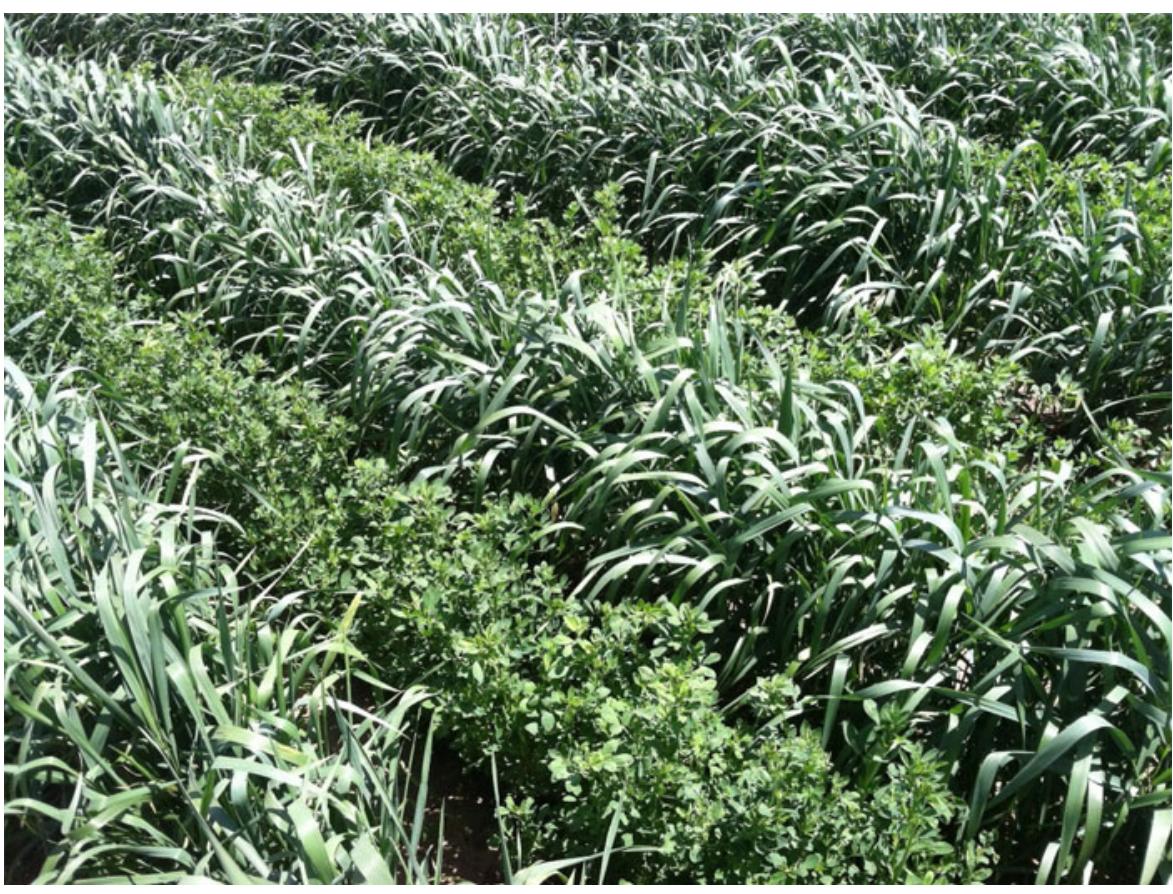

Fig. 7. Polyculture of intermediate wheatgrass or Kernza (Thinopyrum intermedium) and the perennial legume alfalfa (Medicago sativa) grown at The Land Institute. turn leading to an impetus to increase farm sizes (corresponding to economic concentration in the farming sector) and further technological innovation [161] (Figure 8).

This process implies that a minority of early non-risk-aversive adopters reap the benefits of new agricultural technologies, while the majority of farmers are forced to adopt in order to reduce their costs under increasing competition and falling prices. As an illustration, the majority of small farms in the USA, approximately $90 \%$ of all farms, had negative profits in 2016, in sharp contrast to the $3 \%$ of large and very large farms [162].

Mechanization and the pursuit of low-cost chemical substitutes to more labour-intensive practices (e.g. for weeding) are also the main drivers behind many of the ecosystem disservices outlined above. Economic consolidation and the relentless pursuit of economic efficiency in this way has had combined consequences for the environment and for the social fabric of rural societies. The effect of the economic consolidation of the seed industry (which to a large extent is the same as the pesticide industry) is shown in the diagram below by the steep increase of relative prices of seeds (Figure 9). Economically, perennial crops would have the potential to reduce the need for external inputs, particularly seeds, machinery, and fuel, and hence provide a viable alternative for farmers.

Conceivably then, an agricultural system relying on a radically different agroecological approach will need to also be organized in radically different social and economic ways [163]. In other words, what is required is a food production system that is not only more environmentally sustainable, but that also re-values farming as a crucially important social and environmental service and therewith brings renewed employment opportunities to the sector. More interdisciplinary research that takes on these interlinked socio-economic and ecological dimensions will help inform the policies and socio-economic organization of agriculture that is most conducive to a biodiverse and perennial food provisioning system.

Finally, more research is needed on the process of transition itself, to help understand the inertia of ingrained practices and institutions, the political and economic stakes involved in perpetuating the current agricultural model, and the opportunities for confronting them. Notably, the transition to perennial polycultures would be a goal-oriented transition, rather than an emergent one [164]. As with similar radical innovations, this implies that it may not offer immediate user benefits, and that perennial crops may not match the price/performance of monoculture annual practices. The profound social and institutional changes that will be required to make them viable and to ensure the ultimate replacement of annual monocultures are therefore unlikely to come about without political engagement. The successes and failures of the ongoing energy transition can offer important lessons in this respect. As with renewable energy, governments could use a combination of legal and financial instruments to bring about an agricultural transition. Current agricultural subsidy mechanisms could be replaced with targeted agro-environmental incentives [165], and financial support structures created to facilitate the conversion of farms from annual to perennial cropping, as already exists in Europe for the conversion to organic production [166]. Such financial mechanisms would be important in compensating for the economic disadvantage of growing lower-yielding perennial crops, certainly in the beginning. That being said, the tardiness of these regulatory efforts in the case of the energy transition, and the urgency of the problem, may warrant more direct political interventions to ban certain practices or substances and stipulate the use of others, so as to quickly move agriculture in a more sustainable direction. This should be accompanied by efforts to increase transparency in the food production system and the reduction of business influence in agricultural policy making [165]. There are ample opportunities for governments to improve the social and economic attractiveness of perennial crops, making this mostly a question of political will.

The necessity to reduce the environmental impacts of agriculture may ultimately drive such policy changes in favour of perennial grains. The rapid increase in pest resistance, particularly herbicides [66], may become a strong trigger in combination with the increasing awareness of potential health hazards of 
Fig. 8. Graphic representation of the Agricultural Treadmill based on the concept introduced by William Cochran in 1958 [161].
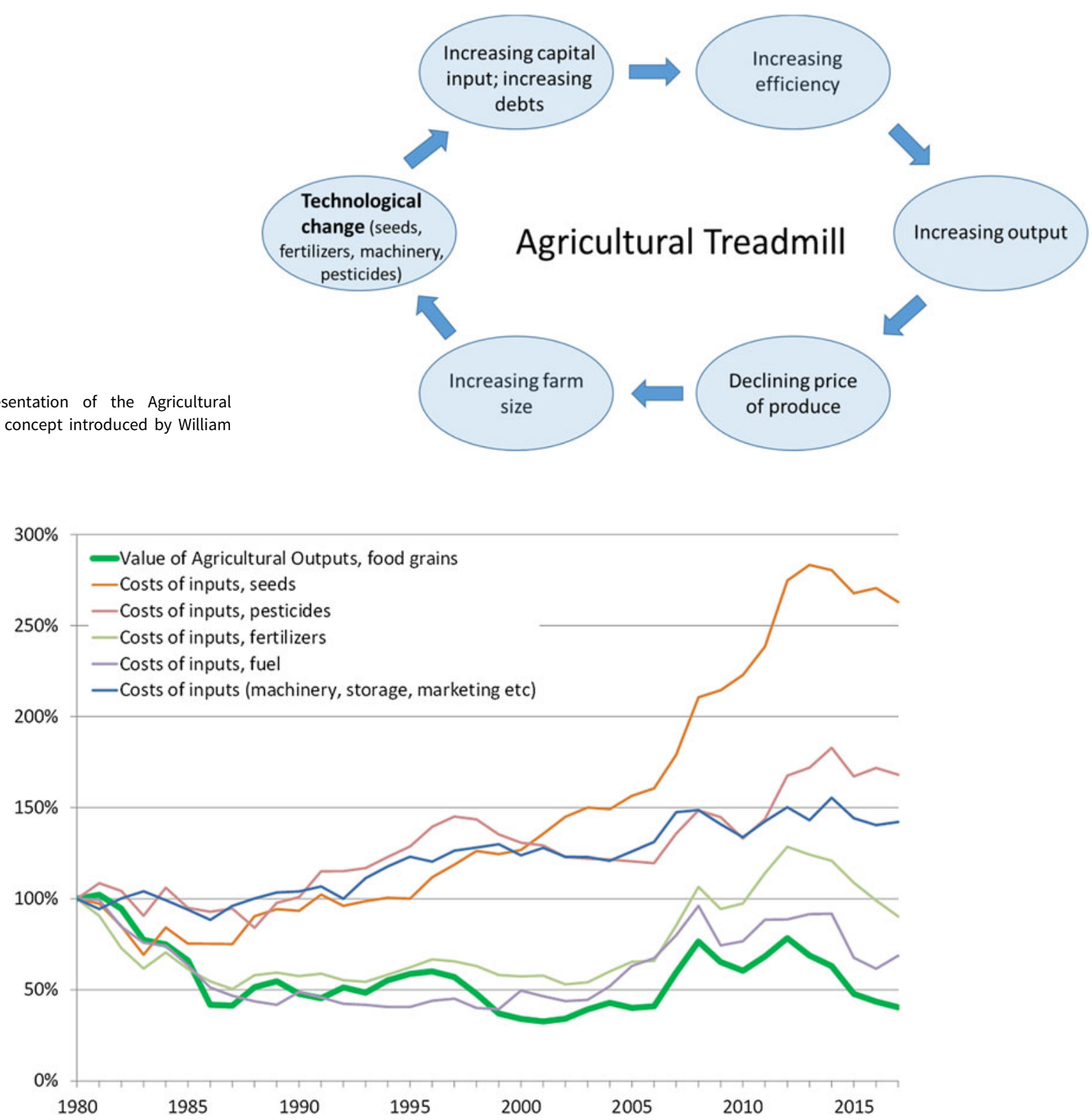

Fig. 9. Diagram showing the relative value of food grains produced in the USA since 1980 in relation to the relative prices of agricultural inputs. Data are in real USD (2017). Source: USDA Economic Research Service, farm income and wealth statistics.

glyphosate [57]. Similarly, the ambitious target of limiting global warming to between 1.5 and $2.0^{\circ} \mathrm{C}$ has put focus on the need and potential for soil carbon sequestration, where perennial grains hold substantial promise. Emission reduction efforts in agriculture will also need to focus on ruminant livestock products (meat and dairy). Kernza could become an important crop in this context by allowing integrated crop and livestock production with lower net greenhouse gas emissions than conventional annual fodder plants [167].

Inevitably, these changes will involve political and economic power struggles, and they are certain to be resisted by vested interests. The agriculture and food sector is dominated by large firms that thrive on the current agricultural model and that have significant political power and a strong advantage over pioneers and niche innovations [168-171]. Documents released in relation to litigation against Monsanto about glyphosate (Roundup) causing cancer reveal how far the industry is prepared to go in defending their products $[172,173]$. Understanding these dynamics will be crucial for formulating strategies and pathways towards a perennial and biodiverse agricultural future.

Despite these challenges, several conditions and trends are favourable for a transition to perennial grains. For farm economics perennial grains hold an important promise, namely the potential to significantly reduce the expenses for external agricultural inputs such as seeds, herbicides, synthetic fertilizers, fuel, and labour, representing approximately $50 \%$ of all farm expenses [174]. This could be a strong incentive for farmers to adopt perennial grains, particularly the great majority of small farms currently operating at very low or even negative profit margins [162]. Furthermore, as shown in Figure 9, there is a growing gap between the relative prices of produce and agricultural inputs which increases the relevance of adopting perennial grains. 
Organic agriculture, of which perennial grains can be considered a radical form, is growing rapidly worldwide both in terms of acreage, sales, and market shares [165]. Data from a recent global survey show that from 1999 to 2016 the area under organic agriculture increased five times, from 11 to $58 \mathrm{mha}$, with the strongest growth after 2012. The global market for organic food increased by $10 \%$ in 2016 with Europe and North America as the main engines of growth. In some European countries (notably France and Ireland), the market for organic products increased by $20 \%$ or more in 2016, and the market share in several countries is approaching $10 \%$ [175]. We see no reason to assume that perennial agriculture could not achieve something similar. Indeed, given how organic farmers are presumably more inclined to appreciate the merits of perennial grains than conventional farmers, the transition to perennial agriculture could conceivably begin within the growing organic food movement.

\section{Concluding remarks}

Humans have become reliant on a food-producing ecosystem that is not sustainable. It is not sustainable because it commonly loses soil faster than soil is formed, it loses SOM, it leaks nutrients and other chemicals that pollute water bodies, it invites weeds, pest insects and diseases, it threatens pollinators, and it now relies on vast expenditures of fossil fuels to maintain production. In general, native ecosystems do not have or cause these problems. As Pimentel and Pimentel suggest, if our agriculture could be designed to function more like natural ecosystems, then it would be easier to maintain, more ecologically sound and sustainable [9]. These ideas have been voiced by Wes Jackson, the co-founder of The Land Institute, since 1980 when he wrote 'New roots for agriculture'. We have argued here that the two greatest obstacles standing in the way of a more natural systems-inspired agriculture, are the existence of perennial crops, and knowledge on how to assemble and maintain a wide diversity of perennial crops on the landscape. Work on developing perennial grain crops is receiving considerable attention $[118,120]$, but projects take decades to bring to fruition, and more participants are needed to develop perennial crops suitable for the many cultures and geographic settings around the world. One possibility worthy of consideration would be the establishment of a new Consortium of International Agricultural Research Centers (CGIAR; formerly known as Consultative Group for International Agricultural Research) centre for the development of biome-specific perennial polycultures. Such a centre could build on efforts of existing centres such as the World Agroforestry Centre (ICRAF) and the International Crops Research Institute for the Semi-arid Tropics (ICRISAT), and could help orchestrate global efforts in plant breeding and agronomy as well as social and economic strategies for uptake and adoption.

It is clearly necessary to make this transition. We suggest that humans now also have the capacity to do so. Agricultural landscapes could be redesigned to nourish a growing population in a warmer world, while stewarding the soil and the diversity of plants and animals that sustain us. Agriculture could provide meaningful jobs in a solar-based and circular economy while revitalizing rural communities and re-valuing the important work that farmers do for society. It could reduce soil disturbances and degradation, retain nutrients and therefore restore and maintain the ecological integrity of agricultural lands. It could rely on the use of agrochemicals - fertilizers, herbicides and pesticides only in exceptional cases rather than as normal practice. It could be based on crop diversity in space and time and on the cultivation of hardy and resilient perennial species, reducing the risks associated with extreme weather events and pest infestations. This would not only protect ecosystems from soil erosion and environmental pollution, it would contribute to climate change mitigation through decreased agricultural inputs and increases in soil carbon sequestration. All of this is an entirely feasible vision of the future. Granted, it will be a tall order, requiring social, economic and political changes as well a technological ones, but it is a future we can choose.

Acknowledgments. The authors acknowledge colleagues at The Land Institute in Salina, KS, USA, and at LUCSUS (Lund University Centre for Sustainability Studies), for constructive comments and inspiration to this review paper. Ideas central to this paper grew out of involvement in the 2017 Kansas Journal of Law and Public Policy Symposium titled 'Grasslands: Balancing preservation and agriculture in the world's most imperiled ecosystem' at which a shorter review was presented: Crews, T. E. (2017). Closing the gap between grasslands and grain agriculture. Kansas Journal of Law and Public Policy, 26, 274.

Author contributions. TEC designed the paper, outlined the overall argument, and wrote the sections on ecosystem services and disservices, as well as the sections on opportunities and challenges in perennial grain agriculture. WC aided in structuring the text and drafted sections on agriculture and climate change, socio-economic obstacles and the process of transition. LO conceived the idea of the paper, wrote the sections on the socio-economic characteristics of current agriculture, contributed to the parts on insecticide and herbicide use. TEC, WC, and LO contributed equally in the editing of the final manuscript.

Financial support. This work was supported by the Swedish research council Formas through the Linnaeus Centre LUCID (grant number 259-2008-1718) and The Swedish Research Council VR (grant number (2016-06300).

Conflict of interest. None.

Ethical standards. This research and article complies with Global Sustainability's publishing ethics guidelines.

\section{References}

1. Power, A. G. (2010). Ecosystem services and agriculture: tradeoffs and synergies. Philosophical Transactions of the Royal Society B: Biological Sciences, 365(1554), 2959-2971.

2. Crews, T. E., Blesh, J., Culman, S. W., Hayes, R. C., Steen Jensen, E., Mack, M. C., Peoples, M. B. \& Schipanski, M. E. (2016). Going where no grains have gone before: from early to mid-succession. Agriculture, Ecosystems and Environment, 223, 223-238.

3. Head, J. W. (2012). Global legal regimes to protect the world's grasslands. Carolina: Carolina Academic Press.

4. Suttie, J. M., Reynolds, S. G., \& Batello, C. (2005). Grasslands of the world. Rome: Food and Agriculture Organization of the United Nations.

5. Sanderman, J., Hengl, T., \& Fiske, G. J. (2017). Soil carbon debt of 12,000 years of human land use. Proceedings of the National Academy of Sciences of the United States of America, 114(36), 9575-9580.

6. Smil, V. (1994). Energy in world history. Winnipeg: University of Manitoba.

7. Gliessman, S. R. (2007). Agroecology: the ecology of sustainable food systems (2nd edition). Florida: CRC Press.

8. Malm, A. (2016). Fossil capital: the rise of steam power and the roots of global warming. London: Verso.

9. Pimentel, D., \& Pimentel, M. (2007). Food, energy, and society. Florida: CRC Press.

10. Sassenrath, G. F., Heilman, P., Luschei, E., Bennett, G. L., Fitzgerald, G., Klesius, P., Tracy, W., Williford, J. R., \& Zimba, P. V. (2008). Technology, 
complexity and change in agricultural production systems. Renewable Agriculture and Food Systems, 23(4), 285-295.

11. MacDonald, J. M., Korb, P., \& Hoppe, R. A. (2013). Farm size and the organization of U.S. crop farming. Washington, D.C., USA: Economic Research Service.

12. Foley, J. A., Ramankutty, N., Brauman, K. A., Cassidy, E. S., Gerber, J. S., Johnston, M., Mueller, N. D., O'Connell, C., Ray, D. K., West, P. C., Balzer, C., Bennett, E. M., Carpenter, S. R., Hill, J., Monfreda, C., Polasky, S., Rockström, J., Sheehan, J., Siebert, S., Tilman, D., \& Zaks, D. P. M. (2011). Solutions for a cultivated planet. Nature, 478 (7369), 337-342.

13. Ewel, J. J. (1999). Natural systems as models for the design of sustainable systems of land use. Agroforestry Systems, 45(1/3), 1-21.

14. Crews, T. E., \& Cattani, D. J. (2018). Strategies, advances, and challenges in breeding perennial grain crops. Sustainability (Switzerland), 10(7), 2192.

15. Wright, E. O. (2010). Envisioning real utopias. London: Verso.

16. Wright, E. O. (2007). Guidelines for envisioning real utopias. Soundings, 36(Summer), 26-39.

17. Brady, N. C., \& Weil, R. R. (2010). Elements of the nature and properties of soils (3rd edition). Essex: Pearson Educational International.

18. Bardgett, R. D., \& Van Der Putten, W. H. (2014). Belowground biodiversity and ecosystem functioning. Nature, 515(7528), 505-511.

19. Delgado-Baquerizo, M., Oliverio, A. M., Brewer, T. E., Benavent-González, A., Eldridge, D. J., Bardgett, R. D., Maestre, F. T., Singh, B. K., \& Fierer, N. (2018). A global atlas of the dominant bacteria found in soil. Science, 359(6373), 320-325.

20. Jenny, H. (1980). The soil resource: origin and behavior (Ecological studies; v. 37). New York: Springer-Verlag.

21. Montgomery, D. R. (2007). Soil erosion and agricultural sustainability. Proceedings of the National Academy of Sciences of the United States of America, 104(33), 13268-13272.

22. Crews, T. E., \& Rumsey, B. E. (2017). What agriculture can learn from native ecosystems in building soil organic matter: a review. Sustainability (Switzerland), 9(4), 1-18.

23. Tilman, D. (1982). Resource competition and community structure. New Jersey: Princeton University Press.

24. Olson, D., \& Cox, R. (2017). California Central Valley Grasslands. World Wildlife Fund. Retrieved from https://www.worldwildlife.org/ecoregions/ na0801

25. Ryals, R., \& Silver, W. L. (2013). Effects of organic matter amendments on net primary productivity and greenhouse gas emissions in annual grasslands. Ecological Applications, 23(1), 46-59.

26. Hillel, D. (1992). Out of the earth: civilization and the life of the soil. California: University of California Press.

27. Vezina, K., Bonn, F., \& Van, C. P. (2006). Agricultural land-use patterns and soil erosion vulnerability of watershed units in Vietnam's northern highlands. Landscape Ecology, 21(8), 1311-1325.

28. Montgomery, D. R. (2007). Dirt: the erosion of civilizations. California: University of California Press.

29. Panagos, P., Borrelli, P., Poesen, J., Ballabio, C., Lugato, E., Meusburger, K., Montanarella, L., \& Alewell, C. (2015). The new assessment of soil loss by water erosion in Europe. Environmental Science and Policy, 54, 438-447.

30. Food and Agriculture Organization (2015). Status of the world's soil resources: technical summary. ISBN 978-92-5-109004-6. Rome: Food and Agriculture Organization.

31. Jackson, W. (1980). New roots for agriculture. Nebraska: University of Nebraska Press.

32. Davidson, E. A., \& Ackerman, I. L. (1993). Changes in soil carbon inventories following cultivation of previously untilled soils. Biogeochemistry, 20(3), 161-193.

33. Schmidt, M. W. I., Torn, M. S., Abiven, S., Dittmar, T., Guggenberger, G., Janssens, I. A., Kleber, M., Kögel-Knabner, I., Lehmann, J., Manning, D. A. C., Nannipieri, P., Rasse, D. P., Weiner, S., \& Trumbore, S. E. (2011). Persistence of soil organic matter as an ecosystem property. Nature, 478(7367), 49-56.

34. Saugier, B., Roy, J. \& Mooney, H. A. (2001) Estimations of global terrestrial productivity: converging toward a single number? In J. Roy,
B. Saugier, \& H. A Mooney (eds), Terrestrial global productivity (pp. 543-557). San Diego: Academic Press.

35. Douds, D. D., \& Seidel, R. (2012). The contribution of arbuscular mycorrhizal fungi to the success or failure of agricultural practices. In $\mathrm{T}$. E. Cheeke, D. C. Coleman, \& D. H. Wall (eds), Microbial ecology in sustainable agroecosystems (pp. 133-152). Florida: CRC Press.

36. Chapin, F. S., Matson, P. A., Vitousek, P. M., \& Chapin, M. C. (2011). Principles of terrestrial ecosystem ecology (2nd ed.). Berlin: Springer Science \& Business Media.

37. Goudrian, J., Goot, J. J. R., \& Uithol, P. W. J. (2001). Productivity of agro-ecosystems. In J. Roy, B. Saugier, \& H. A Mooney (eds), Terrestrial global productivity (pp. 301-314). San Diego: Academic Press.

38. Grandy, A. S., \& Neff, J. C. (2008). Molecular C dynamics downstream: the biochemical decomposition sequence and its impact on soil organic matter structure and function. Science of the Total Environment, 404(2-3), 297-307.

39. Rillig, M. C. (2004). Arbuscular mycorrhizae, glomalin, and soil aggregation. Canadian Journal of Soil Science, 84(4), 355-363.

40. Lal, R. (2011). Sequestering carbon in soils of agro-ecosystems. Food Policy, 36(Suppl. 1), 33-39.

41. DeLuca, T. H., \& Zabinski, C. A. (2011). Prairie ecosystems and the carbon problem. Frontiers in Ecology and the Environment, 9(7), 407-413.

42. Le Quéré, C., Moriarty, R., Andrew, R. M., Canadell, J. G., Sitch, S., Korsbakken, J. I., Friedlingstein, P., Peters, G. P., Andres, R. J., Boden, T. A., Houghton, R. A., House, J. I., Keeling, R. F., Tans, P., Arneth, A., Bakker, D. C. E., Barbero, L., Bopp, L., Chang, J., Chevallier, F., Chini, L. P., Ciais, P., Fader, M., Feely, R. A., Gkritzalis, T., Harris, I., Hauck, J., Ilyina, T., Jain, A. K., Kato, E., Kitidis, V., Klein Goldewijk, K., Koven, C., Landschützer, P., Lauvset, S. K., Lefèvre, N., Lenton, A., Lima, I. D., Metzl, N., Millero, F., Munro, D. R., Murata, A., Nabel, J. E. M. S., Nakaoka, S., Nojiri, Y., O’Brien, K., Olsen, A., Ono, T., Pérez, F. F., Pfeil, B., Pierrot, D., Poulter, B., Rehder, G., Rödenbeck, C., Saito, S., Schuster, U., Schwinger, J., Séférian, R., Steinhoff, T., Stocker, B. D., Sutton, A. J., Takahashi, T., Tilbrook, B., van der Laan-Luijkx, I. T., van der Werf, G. R., van Heuven, S., Vandemark, D., Viovy, N., Wiltshire, A., Zaehle, S., \& Zeng, N. (2015). Global Carbon Budget 2015. Earth System Science Data, 7, 349-396.

43. Griscom, B. W., Adams, J., Ellis, P. W., Houghton, R. A., Lomax, G., Miteva, D. A., Schlesinger, W. H., Shoch, D., Siikamäki, J. V., Smith, P., Woodbury, P., Zganjar, C., Blackman, A., Campari, J., Conant, R. T., Delgado, C., Elias, P., Gopalakrishna, T., Hamsik, M. R., Herrero, M., Kiesecker, J., Landis, E., Laestadius, L., Leavitt, S. M., Minnemeyer, S., Polasky, S., Potapov, P., Putz, F. E., Sanderman, J., Silvius, M., Wollenberg, E., \& Fargione, J. (2017). Natural climate solutions. Proceedings of the National Academy of Sciences of the United States of America, 114(44), 11645-11650.

44. Brookes, P. (2001). The soil microbial biomass: concept, measurement and applications in soil ecosystem research. Microbes and Environments, 16(3), 131-140.

45. Dick, R. P. (2013). Microbial ecology in sustainable agroecosystems. In T. E. Cheeke, D. C. Coleman, \& D. H. Wall (eds), Microbial ecology in sustainable agroecosystems (pp. 23-48). Florida: CRC Press.

46. Steenwerth, K. L., Jackson, L. E., Calderon, F. J., Stromberg, M. R., \& Scow, K. M. (2002). Soil microbial community composition and land use history in cultivated and grassland ecosystems of coastal California. Soil Biology \& Biochemistry, 34(11), 1599-1611.

47. Culman, S. W., DuPont, S. T., Glover, J. D., Buckley, D. H., Fick, G. W., Ferris, H., \& Crews, T. E. (2010). Long-term impacts of high-input annual cropping and unfertilized perennial grass production on soil properties and belowground food webs in Kansas, USA. Agriculture, Ecosystems and Environment, 137(1-2), 13-24.

48. Li, N., Yao, S. H., You, M. Y., Zhang, Y. L., Qiao, Y. F., Zou, W. X. Han, X. Z., \& Zhang, B. (2014). Contrasting development of soil microbial community structure under no-tilled perennial and tilled cropping during early pedogenesis of a Mollisol. Soil Biology and Biochemistry, $77,221-232$.

49. Rosenzweig, S. T., Carson, M. A., Baer, S. G., \& Blair, J. M. (2016). Changes in soil properties, microbial biomass, and fluxes of $\mathrm{C}$ and $\mathrm{N}$ 
in soil following post-agricultural grassland restoration. Applied Soil Ecology, 100, 186-194.

50. Rasche, F., Blagodatskaya, E., Emmerling, C., Belz, R., Musyoki, M. K., Zimmermann, J., \& Martin, K. (2017). A preview of perennial grain agriculture: knowledge gain from biotic interactions in natural and agricultural ecosystems. Ecosphere, 8(12), e02048.

51. Bever, J. D., Platt, T. G., \& Morton, E. R. (2012). Microbial population and community dynamics on plant roots and their feedbacks in plant communities. Annual Review of Microbiology, 66(131), 265-283.

52. Koziol, L., Bever, J. D., \& Hawkes, C. V. (2015). Mycorrhizal response trades off with plant growth rate and increases with plant successional status. Ecology, 96(7), 1768-1774.

53. Huggins, D. R., \& Reganold, J. P. (2008). No-till: the quiet revolution. Scientific American, (July), 71-77.

54. Derpsch, R., Friedrich, T., Kassam, A., \& Hongwen, L. (2010). Current status of adoption of no-till farming in the world and some of its main benefits. International Journal of Agricultural and Biological Engineering, 3(1), 1-25.

55. Six, J., Elliot, E. T., \& Paustian, K. (2000). Soil microaggregate turnover and microaggregate formation: a mechanism for $\mathrm{C}$ organic under no-tillage agriculture. Soil Biology and Biochemistry, 32(14), 2099-2103.

56. VandenBygaart, A. J. (2016). The myth that no-till can mitigate global climate change. Agriculture, Ecosystems and Environment, 216, 98-99.

57. Cressey, D. (2015). Widely used herbicide linked to cancer. Nature News. Retrieved from https://www.nature.com/news/widely-used-herbicidelinked-to-cancer-1.17181

58. Ward, E. M. (2018). Glyphosate use and cancer incidence in the agricultural health study: an epidemiologic perspective. Journal of the National Cancer Institute, 110(5), 446-447.

59. Andreotti, G., Koutros, S., Hofmann, J. N., Sandler, D. P., Lubin, J. H., Lynch, C. F., Lerro, C. C., De Roos, A. J., Parks, C. G., Alavanja, M. C., Silverman, D. T., \& Beane Freeman, L. E. (2017). Glyphosate use and cancer incidence in the agricultural health study. Journal of the National Cancer Institute, 110(5), 509-516.

60. Hassan, S. A., Akhlaq, F., Tayyab, M., Awan, A. R., Firyal, S., Khan, W. A., Saif, R., \& Wasim, M. (2017). Glyphosate: cancerous or not? Perspectives from both ends of the debate. Advancements in Life Sciences - International Quarterly Journal of Biological Sciences, 4(4), 108-112.

61. Rose, M. T., Cavagnaro, T. R., Scanlan, C. A., Rose, T. J., Vancov, T., Kimber, S., Kennedy, I. R., Kookana, R. S., \& Van Zwieten, L. (2016). Impact of herbicides on soil biology and function. Advances in Agronomy, 136, 133-220.

62. Bomfim, N. C. P., Costa, B. G. P., Souza, L. A., Justino, G. C., Aguiar, L. F., \& Camargos, L. S. (2017). Glyphosate effect on nitrogen fixation and metabolization in RR soybean. Journal of Agricultural Science, 9(10), 114.

63. Gaupp-Berghausen, M., Hofer, M., Rewald, B., \& Zaller, J. G. (2015). Glyphosate-based herbicides reduce the activity and reproduction of earthworms and lead to increased soil nutrient concentrations. Scientific Reports, 5, 12886.

64. Zaller, J. G., Heigl, F., Ruess, L., \& Grabmaier, A. (2014). Glyphosate herbicide affects belowground interactions between earthworms and symbiotic mycorrhizal fungi in a model ecosystem. Scientific Reports, 4 , 5634.

65. Druille, M., García-Parisi, P. A., Golluscio, R. A., Cavagnaro, F. P., \& Omacini, M. (2016). Repeated annual glyphosate applications may impair beneficial soil microorganisms in temperate grassland. Agriculture, Ecosystems \& Environment, 230, 184-190.

66. Gould, F., Brown, Z. S., \& Kuzma, J. (2018). Wicked evolution: can we address the sociobiological dilemma of pesticide resistance? Science, 360(6390), 728-732.

67. Center for Food Safety (2015). Lawsuit Challenging EPA Approval of Herbicide Advances. Retrieved from https://www.centerforfoodsafety.org/ press-releases/4103/lawsuit-challenging-epa-approval-of-harmful-herbicideadvances\#

68. Mortensen, D. A., Egan, J. F., Maxwell, B. D., Ryan, M. R., \& Smith, R. G. (2012). Navigating a critical juncture for sustainable weed management. BioScience, 62(1), 75-84.
69. Vitousek, P. M., \& Reiners, W. A. (2013). Ecosystem succession and nutrient retention: a hypothesis. BioScience, 25(6), 376-381.

70. Elser, J. J., Bracken, M. E. S., Cleland, E. E., Gruner, D. S., Harpole, W. S., Hillebrand, H., Ngai, J. T., Seabloom, E. W., Shurin, J. B., \& Smith, J. E. (2007). Global analysis of nitrogen and phosphorus limitation of primary producers in freshwater, marine and terrestrial ecosystems. Ecology Letters, 10(12), 1135-1142.

71. Sharpley, A., \& Rekolainen, S. (1997). Phosphorus in agriculture and its environmental implications. In H. Tunney et al. (ed), Phosphorus loss from soil to water (pp. 1-54). Cambridge: CAB International Press.

72. United Nations Environment Programme. Why is eutrophication such a serious pollution problem. Division of Technology, Industry and Economics: newsletter and technical publications: lakes and reservoirs vo. 3. Retrieved from http://www.unep.or.jp/ietc/publications/short_series/lakereservoirs-3/ 1.asp

73. Broussard, W., \& Turner, R. E. (2009). A century of changing land-use and water-quality relationships in the continental US. Frontiers in Ecology and the Environment, 7(6), 302-307.

74. Rabalais, N. N., Díaz, R. J., Levin, L. A., Turner, R. E., Gilbert, D., \& Zhang, J. (2010). Dynamics and distribution of natural and humancaused hypoxia. Biogeosciences, 7(2), 585-619.

75. Turner, R. E., \& Rabalais, N. N. (2009). Linking landscape and water quality in the Mississippi river basin for 200 years, 53(6), 563-572.

76. Diaz, R. J., \& Rosenberg, R. (2008). Spreading dead zones and consequences for marine ecosystems. Science, 321(5891), 926-929.

77. Marschner, H. (1995). Mineral nutrition of higher plants. 1, 889. London: Academic Press Retrieved from http://dx.doi.org/10.1006/ anbo.1996.0155

78. Basche, A., \& DeLonge, M. (2017). The impact of continuous living cover on soil hydrologic properties: a meta-analysis. Soil Science Society of America Journal, 81(5), 1179.

79. Schenk, H. J., \& Jackson, R. B. (2002). Rooting depths, lateral root spreads and belowground aboveground allometries of plants in water limited ecosystems. Journal of Ecology, 90(3), 480-494.

80. Wuest, S. B., Williams, J. D., \& Gollany, H. T. (2006). Tillage and perennial grass effects on ponded infiltration for seven semi-arid loess soils. Journal of Soil and Water Conservation, 61(4), 218-223.

81. Rockstrom, J. (2003). Water for food and nature in drought-prone tropics: vapour shift in rain-fed agriculture. Philosophical Transactions of the Royal Society B: Biological Sciences, 358(1440), 1997-2009.

82. Falkenmark, M., \& Rockström, J. (2008). Building resilience to drought in desertification-prone savannas in Sub-Saharan Africa: the water perspective. Natural Resources Forum, 32(2), 93-102.

83. Hudson, B. D. (1994). Soil organic matter and available water capacity. Journal of Soil \& Water Conservation, 49(2), 189-194.

84. Lal, R. (2004). Soil carbon sequestration impacts on global climate change and food security. Science, 304(5677), 1623-1627.

85. Cardinale, B. J., Duffy, J. E., Gonzalez, A., Hooper, D. U., Perrings, C., Venail, P., Narwani, A., MacE, G. M., Tilman, D., Wardle, D. A., Kinzig, A. P., Daily, G. C., Loreau, M., Grace, J. B., Larigauderie, A., Srivastava, D. S., \& Naeem, S. (2012). Biodiversity loss and its impact on humanity. Nature, 486(7401), 59-67.

86. Weisser, W. W., Roscher, C., Meyer, S. T., Ebeling, A., Luo, G., Allan, E., Beßler, H., Barnard, R. L., Buchmann, N., Buscot, F., Engels, C., Fischer, C., Fischer, M., Gessler, A., Gleixner, G., Halle, S., Hildebrandt, A., Hillebrand, H., de Kroon, H., Lange, M., Leimer, S., Le Roux, X., Milcu, A., Mommer, L., Niklaus, P. A., Oelmann, Y., Proulx, R., Roy, J., Scherber, C., Scherer-Lorenzen, M., Scheu, S., Tscharntke, T., Wachendorf, M., Wagg, C., Weigelt, A., Wilcke, W., Wirth, C., Schulze, E. D., Schmid, B., \& Eisenhauer, N. (2017). Biodiversity effects on ecosystem functioning in a 15 -year grassland experiment: patterns, mechanisms, and open questions. Basic and Applied Ecology, 23, 1-73.

87. Duffy, J. E., Godwin, C. M., \& Cardinale, B. J. (2017). Biodiversity effects in the wild are common and as strong as key drivers of productivity. Nature, 549(7671), 261-264.

88. Hooper, D. U., \& Dukes, J. S. (2004). Overyielding among plant functional groups in a long-term experiment. Ecology Letters, 7(2), 95-105. 
89. DeHaan, L. R., Weisberg, S., Tilman, D., \& Fornara, D. (2010). Agricultural and biofuel implications of a species diversity experiment with native perennial grassland plants. Agriculture, Ecosystems and Environment, 137(1-2), 33-38.

90. Cardon, Z. G., Stark, J. M., Herron, P. M., \& Rasmussen, J. A. (2013). Sagebrush carrying out hydraulic lift enhances surface soil nitrogen cycling and nitrogen uptake into inflorescences. Proceedings of the National Academy of Sciences of the United States of America, 110(47), 1898818993.

91. Loreau, M., \& Hector, A. (2001). Partitioning selection and complementarity in biodiversity experiments. Nature, 412(6842), 72-76.

92. Bever, J. D., Mangan, S. A., \& Alexander, H. M. (2015). Maintenance of plant species diversity by pathogens. Annual Review Ecology Evolution and Systematics 46, 305-325.

93. Smith, V. H., McBride, R. C., Shurin, J. B., Bever, J. D., Crews, T. E., \& Tilman, G. D. (2015). Crop diversification can contribute to disease risk control in sustainable biofuels production. Frontiers in Ecology and the Environment, 13(10), 561-567.

94. Schnitzer, S. A., Klironomos, J. N., Hillerislambers, J., Kinkel, L. L., Reich, P. B., Xiao, K., Rillig, M. C., Sikes, B. A., Callaway, R. M., Mangan, S. A., Van Nes, E. H., \& Scheffer, M. (2011). Soil microbes drive the classic plant diversity-productivity pattern. Ecology, 92(2), 296-303. Retrieved from https://kuscholarworks.ku.edu/bitstream/handle/1808/13669/Sikes_et_al_2011.pdf?sequence $=1$

95. Vandermeer, J. H. (2011). The ecology of agroecosystems. Massachusetts: Jones \& Bartlett Learning.

96. Liebman, M. (1995). Polyculture cropping systems. In M. A. Altieri (ed), Agroecology (pp. 205-218). Florida: CRC Press.

97. Altieri, M. A. (1995). Agroecology, the science of sustainable agriculture. Florida: CRC Press.

98. Pimentel, D. (1961). Species diversity and insect population outbreaks. Annals of the Entomological Society of America, 54(1), 76-86.

99. Elton, C. S. (1958). The ecology of invasions by animals and plants. London: Methuen.

100. Root, R. B. (1973). Organization of a plant-arthropod association in simple and diverse habitats: the fauna of collards (Brassica oleracea). Ecological Monographs, 43(1), 95-124.

101. Mazoyer, M., \& Roudart, L. (2006). A history of world agriculture: from the neolithic age to the current crisis. London: Earthscan.

102. Crews, T. E., \& Peoples, M. B. (2004). Legume versus fertilizer sources of nitrogen: ecological tradeoffs and human needs. Agriculture, Ecosystems and Environment, 102(3), 279-297.

103. Oerke, E. C. (2006). Crop losses to pests. Journal of Agricultural Science, $144,31-43$.

104. Pimentel, D., Acquay, H., Biltonen, M., Rice, P., Silva, M., Nelson, J., Lipner, V., Giordano, S., Horowitz, A., \& D’Amore, M. (1993). Assessment of environmental and economic impacts of pesticide use. In D. Pimentel, \& H. Lehman (ed), The pesticide question (pp. 47-84). London: Chapman and Hall.

105. Stokstad, E. (2013). How big a role should neonicotinoids play in food security? Science, 340(6133), 675.

106. Budge, G. E., Garthwaite, D., Crowe, A., Boatman, N. D., Delaplane, K. S., Brown, M. A., Thygesen, H. H., \& Pietravalle, S. (2015). Evidence for pollinator cost and farming benefits of neonicotinoid seed coatings on oilseed rape. Scientific Reports, 5, 12574.

107. Simon-Delso, N., Pisa, L., Van der Sluijs, J. P., Amaral-Rogers Buglife, V., Belzunces, L. P., Bonmatin, J. M., Downs, C., Furlan, L., Gibbons, D. W., Giorio, C., Girolami, V., Goulson, D., Kreutzweiser, D. P., Krupke, C. H., Long, E., Liess, M., \& McField, M. (2015). Systemic insecticides (neonicotinoids and fipronil): trends, uses, mode of action and metabolites. Environmental Science and Pollution Research, 22, 5-34.

108. Kurwadkar, S., \& Evans, A. (2016). Neonicotinoids: systemic insecticides and systematic failure. Bulletin of Environmental Contamination and Toxicology, 97(6), 745-748.

109. Carson, R. (1962). Silent spring. Massachusetts: Houghton, Mifflin, Harcourt.

110. Griswold, E. (2012). How 'silent spring' ignited the environmental movement. New York Times Magazine, 1-9.
111. Yudelman, M., Ratta, A., Nygaard, D. F., International Food Policy Research Institute., \& International Development Research Centre (Canada) (1998). Pest management and food production: looking to the future. Washington, D.C.: International Food Policy Research Institute.

112. Stanley, D. A., Garratt, M. P. D., Wickens, J. B., Wickens, V. J., Potts, S. G., \& Raine, N. E. (2015). Neonicotinoid pesticide exposure impairs crop pollination services provided by bumblebees. Nature, 528(7583), 548-550.

113. Klatt, B. K., Rundlöf, M., \& Smith, H. G. (2016). Maintaining the restriction on neonicotinoids in the european union - benefits and risks to bees and pollination services. Frontiers in Ecology and Evolution, 4, 4.

114. Hallmann, C. A., Sorg, M., Jongejans, E., Siepel, H., Hofland, N., Schwan, H., Stenmans, W., Müller, A., Sumser, H., Hörren, T., Goulson, D., \& De Kroon, H. (2017). More than 75 percent decline over 27 years in total flying insect biomass in protected areas. PLoS ONE, 12(10), e0185809.

115. Flocks, J. D. (2012). The environmental and social injustice of farmworker pesticide exposure. Georgetown Journal on Poverty Law \& Policy, 255 (2), 225-282.

116. Kesavachandran, C. N., Fareed, M., Pathak, M. K., Bihari, V., Mathur, N., \& Kumar Srivastava, A. (2009). Adverse health effects of pesticide in agrarian populations of developing countries. In D. M. Whitacre (ed) Reviews of environmental contamination and toxicology vol. 200. New York: Springer.

117. Van Tassel, D. L., Dehaan, L. R., \& Cox, T. S. (2010). Missing domesticated plant forms: can artificial selection fill the gap? Evolutionary Applications, 3(5-6), 434-452.

118. Baker, B. (2017). Can modern agriculture be sustainable? BioScience, 67 (4), 325-331.

119. Van Tassel, D. L., Albrecht, K. A., Bever, J. D., Boe, A. A., Brandvain, Y., Crews, T. E., Gansberger, M., Gerstberger, P., González-Paleo, L., Hulke, B. S., Kane, N. C., Johnson, P. J., Pestsova, E. G., Picasso Risso, V. D., Prasifka, J. R., Ravetta, D. A., Schlautman, B., Sheaffer, C. C., Smith, K. P., Speranza, P. R., Turner, M. K., Vilela, A. E., von Gehren, P., \& Wever, C. (2017). Accelerating silphium domestication: an opportunity to develop new crop ideotypes and breeding strategies informed by multiple disciplines. Crop Science, 57(3), 1274-1284.

120. Batello, C., Wade, L., Cox, S., Pogna, N., Bozzini, A., \& Choptiany, J. (2014). Perennial crops for food security. Retrieved from http://agris.fao. org/agris-search/search.do?recordID=XF2017002349

121. Nabukalu, P., \& Cox, T. S. (2016). Response to selection in the initial stages of a perennial sorghum breeding program. Euphytica, 209(1), 103-111.

122. Sprunger, C. D., Culman, S. W., Robertson, G. P., \& Snapp, S. S. (2017). Perennial grain on a Midwest Alfisol shows no sign of early soil carbon gain. Renewable Agriculture and Food Systems, 33(4), 360-372.

123. de Oliveira, G., Brunsell, N. A., Sutherlin, C. E., Crews, T. E., \& DeHaan, L. R. (2018). Energy, water and carbon exchange over a perennial Kernza wheatgrass crop. Agricultural and Forest Meteorology, 249, 120-137.

124. Vico, G., \& Brunsell, N. A. (2017). Tradeoffs between water requirements and yield stability in annual vs. perennial crops. Advances in Water Resources, 112, 189-202.

125. Woodmansee, R. (1978). Additions and losses of nitrogen in grassland ecosystems. Bioscience, 28(7), 448-453.

126. Dodds, W. K., Blair, J. M., Henebry, G. M., Koelliker, J. K., Ramundo, R., \& Tate, C. M. (1996). Nitrogen transport from tallgrass prairie watersheds. Journal of Environment Quality, 25(5), 973.

127. Masarik, K. C., Norman, J. M., Brye, K. R., \& Masarik, K. C. (2014). Long-term drainage and nitrate leaching below well-drained continuous corn agroecosystems and a prairie. Journal of Environmental Protection, 5 (5), 240-254.

128. Kahmen, A., Renker, C., Unsicker, S. B., \& Buchmann, N. (2012). Niche complementarity for nitrogen: an explanation for the biodiversity and ecosystem functioning relationship. Ecology, 87(5), 1244-1255.

129. Blair, J. M., Seastedt, T. R., Rice, C. W., \& Ramundo, R. A. (1998). Terrestrial nutrient cycling in tallgrass prairie. In Grassland dynamics: long-term ecological research (pp. 222-243). New York: Oxford University Press. 
130. Culman, S. W., Snapp, S. S., Ollenburger, M., Basso, B., \& DeHaan, L. R. (2013). Soil and water quality rapidly responds to the perennial grain Kernza wheatgrass. Agronomy Journal, 105(3), 735-744.

131. Weißhuhn, P., Reckling, M., Stachow, U., \& Wiggering, H. (2017). Supporting agricultural ecosystem services through the integration of perennial polycultures into crop rotations. Sustainability, 9(12), 2267.

132. Cox, C. M., Garrett, K. A., \& Bockus, W. W. (2005). Meeting the challenge of disease management in perennial grain cropping systems. Renewable Agriculture and Food Systems, 20(1), 15-24.

133. Cunfer, B. M., Buntin, G. D., \& Phillips, D. V. (2006). Effect of crop rotation on take-all of wheat in double-cropping systems. Plant Disease, 90 (9), 1161-1166.

134. Reiss, E. R., \& Drinkwater, L. E. (2017). Cultivar mixtures: a meta-analysis of the effect of intraspecific diversity on crop yield. Ecological Applications, 28(1), 62-77.

135. Zhu, Y. (2000). Genetic diversity and disease control in rice. Nature, 406, 718-722.

136. Smith, P., Bustamante, M., Ahammad, H., Clark, H., Dong, H., Elsiddig, E. A., Haberl, H., Harper, R., House, J., Jafari, M., Masera, O., Mbow, C., Ravindranath, N. H., Rice, C. W., Robledo Abad, C., Romanovskaya, A., Sperling, F., \& F. Tubiello (2014). Agriculture, Forestry and Other Land Use (AFOLU). In Climate Change 2014: Mitigation of Climate Change. Contribution of Working Group III to the Fifth Assessment Report of the Intergovernmental Panel on Climate Change (pp. 811-922). Cambridge and New York: Cambridge University Press. Retrieved from https://www.ipcc.ch/pdf/assessmentreport/ar5/wg3/ipcc_wg3_ar5_chapter11.pdf

137. Jensen, E. S., Peoples, M. B., Boddey, R. M., Gresshoff, P. M., Henrik, H. N., Alves, B. J. R., \& Morrison, M. J. (2012). Legumes for mitigation of climate change and the provision of feedstock for biofuels and biorefineries. A review. Agronomy for Sustainable Development, 32(2), 329-364.

138. Glover, J. D., Culman, S. W., DuPont, S. T., Broussard, W., Young, L., Mangan, M. E., Mai, J. G., Crews, T. E., DeHaan, L. R., Buckley, D. H., Ferris, H., Turner, R. E., Reynolds, H. L., \& Wyse, D. L. (2010). Harvested perennial grasslands provide ecological benchmarks for agricultural sustainability. Agriculture, Ecosystems and Environment, 137(1-2), 3-12.

139. IPCC (2014). Climate Change 2014: Impacts, Adaptation, and Vulnerability. Part A: Global and Sectoral Aspects. Contribution of Working Group II to the Fifth Assessment Report of the Intergovernmental Panel on Climate Change (pp.1132). Cambridge and New York: Cambridge University Press.

140. Rosenzweig, C., Elliott, J., Deryng, D., Ruane, A. C., Müller, C., Arneth, A., Boote, K. J., Folberth, C., Glotter, M., Khabarov, N., Neumann, K., Piontek, F., Pugh, T. A. M., Schmid, E., Stehfest, E., Yang, H., \& Jones, J. W. (2014). Assessing agricultural risks of climate change in the 21st century in a global gridded crop model intercomparison. Proceedings of the National Academy of Sciences of the United States of America, 111(9), 3268-3273.

141. Liu, B., Asseng, S., Müller, C., Ewert, F., Elliott, J., Lobell, D. B., Martre, P., Ruane, A., C., Wallach, D., Jones, J. W., Rosenzweig, C., Aggarwal, P. K., Alderman, P. D., Anothai, J., Basso, B., Biernath, C., Cammarano, D., Challinor, A., Deryng, D., De Sanctis, G., Doltra, J., Fereres, E., Folberth, C., Garcia-Vila, M., Gayler, S., Hoogenboom, G., Hunt, L. A., Izaurralde, R. C., Jabloun, M., Jones, C. D., Kersebaum, K. C., Kimball, B. A., Koehler, A. K., Kumar, S. N., Nendel, C., O'Leary, G. J., Olesen, J. E., Ottman, M. J., Palosuo, T., Prasad, P. V. V., Priesack, E., Pugh, T. A. M., Reynolds, M., Rezaei, E. E., Rötter, R. P., Schmid, E., Semenov, M. A., Shcherbak, I., Stehfest, E., Stöckle, C. O., Stratonovitch, P., Streck, T., Supit, I., Tao, F., Thorburn, P., Waha, K., Wall, G. W., Wang, E., White, J. W., Wolf, J., Zhao, Z., \& Zhu, Y. (2016). Similar estimates of temperature impacts on global wheat yield by three independent methods. Nature Climate Change, 6(12), 1130-1136.

142. Challinor, A. J., Watson, J., Lobell, D. B., Howden, S. M., Smith, D. R., \& Chhetri, N. (2014). A meta-analysis of crop yield under climate change and adaptation. Nature Climate Change, 4(4), 287-291.

143. Gepts, P. (2004). Selection experiment. Plant Breeding, 24(2), 1-44.
144. Fu, Y. B. (2015). Understanding crop genetic diversity under modern plant breeding. Theoretical and Applied Genetics, 128(11), 2131-2142.

145. Vico, G., Manzoni, S., Nkurunziza, L., Murphy, K., \& Weih, M. (2016). Trade-offs between seed output and life span - a quantitative comparison of traits between annual and perennial congeneric species. New Phytologist, 209(1), 104-114.

146. DeHaan, L. R., Van Tassel, D. L., \& Cox, T. S. (2005). Perennial grain crops: a synthesis of ecology and plant breeding. Renewable Agriculture and Food Systems, 20(1), 5-14.

147. Crews, T. E., \& DeHaan, L. R. (2015). The strong perennial vision: a response. Agroecology and Sustainable Food Systems, 39(5), 500-515.

148. Milla, R., Morente-Lopez, J., Alonso-Rodrigo, J. M., Martin-Robles, N., \& Stuart Chapin, F. (2014). Shifts and disruptions in resource-use trait syndromes during the evolution of herbaceous crops. Proceedings of the Royal Society B: Biological Sciences, 281(1793), 20141429-20141429.

149. Stuber, C. W., \& Hancock, J. (2008). Sustaining plant breeding-national workshop. Crop Science, 48, 25-29.

150. Price, S. C. (1999). Public and private plant breeding. Nature Biotechnology, 17(10), 938-938.

151. Curwen-McAdams, C., Arterburn, M., Murphy, K., Cai, X., \& Jones, S. S. (2017). Toward a taxonomic definition of perennial wheat: a new species $\times$ Tritipyrum aaseae described. Genetic Resources and Crop Evolution, 64 (7), 1651-1659.

152. Kantar, M. B., Tyl, C. E., Dorn, K. M., Zhang, X., Jungers, J. M., Kaser, J. M., Schendel, R. R., Eckberg, J. O., Runck, B. C., Bunzel, M., Jordan, N. R., Stupar, R. M., Marks, M. D., Anderson, J. A., Johnson, G. A., Sheaffer, C. C., Schoenfuss, T. C., Ismail, B., Heimpel, G. E., \& Wyse, D. L. (2016). Perennial grain and oilseed crops. Annual Review of Plant Biology, 67(1), 703-729.

153. DeHaan, L. R., Van Tassel, D. L., Anderson, J. A., Asselin, S. R., Barnes, R., Baute, G. J., Cattani, D. J., Culman, S. W., Dorn, K. M., Hulke, B. S., Kantar, M., Larson, S., Marks, M. D., Miller, A. J., Poland, J., Ravetta, D. A., Rude, E., Ryan, M. R., Wyse, D., \& Zhang, X. (2016). A pipeline strategy for grain crop domestication. Crop Science, 56(3), 917-930.

154. Dawson, J. C., Rivière, P., Berthellot, J.-F., Mercier, F., Kochko, P. de, Galic, N., Pin, S., Serpolay, E., Thomas, M., Giuliano, S., \& Goldringer, I. (2011). Collaborative plant breeding for organic agricultural systems in developed countries. Sustainability, 3(8), 1206-1223.

155. Kucek, L. K., Darby, H., Mallory, E., Dawson, J., Davis, M., Dyck, E., Lazor, J., O’Donnell, S., Mudge, S., Kimball, M., Molloy, T., Benscher, D., Tanaka, J., Cummings, E., \& Sorrells, M. E. (2015). Participatory breeding of wheat for organic production. In Proceedings of the Organic Agriculture Research Symposium, LaCrosse, WI (pp. 18). LaCrosse, WI. Retrieved from http://eorganic.info/sites/eorganic. info/files/u27/06-Kucek-OARS_Proceedings-2015_10_07-Final_0.pdf

156. Najeeb, S., Sheikh, F. A., Parray, G. A., Shikari, A. B., Zaffar, G., Kashyp, S. C., Ganie, M. A., \& Shah, A. B. (2018). Farmers' participatory selection of new rice varieties to boost production under temperate agro-ecosystems. Journal of Integrative Agriculture, 17(6), 1307-1314.

157. Ceccarelli, S. (2011). Syria - participatory barley breeding - farmers' input becomes everyone's gain. Retrieved from http://repo.mel.cgiar. org/handle/20.500.11766/7813

158. Mendes-Moreira, P., Satovic, Z., Mendes-Moreira, J., Santos, J. P., Nina Santos, J. P., Pêgo, S., \& Vaz Patto, M. C. (2017). Maize participatory breeding in Portugal: Comparison of farmer's and breeder's on-farm selection. Plant Breeding, 136(6), 861-871.

159. Mouchet, M. A., Villéger, S., Mason, N. W. H., \& Mouillot, D. (2010). Functional diversity measures: an overview of their redundancy and their ability to discriminate community assembly rules. Functional Ecology, 24(4), 867-876.

160. Cadotte, M. W., Carscadden, K., \& Mirotchnick, N. (2011). Beyond species: functional diversity and the maintenance of ecological processes and services. Journal of Applied Ecology, 48(5), 1079-1087.

161. Cochrane, W. (1958). Farm prices: myth and reality. Minneapolis: University of Minnesota Press.

162. Hoppe, R. A. (2017). America's diverse family farms: 2017 Edition. Washington, D.C., USA. Retrieved from https://www.ers.usda.gov/webdocs/publications/86198/eib-185.pdf? $v=43083$ 
163. Schipanski, M. E., MacDonald, G. K., Rosenzweig, S. T., Chappell, M. J., Bennett, E. M., Kerr, R. B., Blesh, J., Crews, T. E., Drinkwater, L., Lundgren, J. G., \& Schnarr, C. (2016). Realizing resilient food systems. BioScience, 66(7), 600-610.

164. Geels, F. W. (2011). The multi-level perspective on sustainability transitions: responses to seven criticisms. Environmental Innovation and Societal Transitions, 1(1), 24-40.

165. Reganold, J. P., \& Wachter, J. M. (2016). Organic agriculture in the twenty-first century. Nature Plants, 2(2), 15221.

166. Lohr, L., \& Salomonsson, L. (1998). Conversion subsidies for organic production: results from Sweden and lessons for the United States. Agricultural Economics 22, 133-146.

167. DeHaan, L. R., \& Ismail, B. P. (2017). Perennial cereals provide ecosystem benefits. Cereal Foods World, 62(6), 278-281.

168. Fernandez-Cornejo, J., \& Schimmelpfennig, D. E. (2004). Have seed industry changes affected research effort? Washington, D.C.: United States Department of Agriculture Economic Research Service. Retrieved from https://www.ers.usda.gov/amber-waves/2004/february/have-seed-industrychanges-affected-research-effort/

169. Fuglie, K., Heisey, P., King, J., \& Schimmelpfennig, D. (2012). Rising concentration in agricultural input industries influences new farm technologies. Washington, D.C.: United States Department of Agriculture Economic
Research Service. Retrieved from https://www.ers.usda.gov/amber-waves/ 2012/december/rising-concentration-in-agricultural-input-industries-influences-new-technologies/

170. Schimmelpfennig, D. E., Pray, C. E., \& Brennan, M. F. (2004). The impact of seed industry concentration on innovation: a study of US biotech market leaders. Agricultural Economics, 30(2), 157-167.

171. Elliott, K. C. (2013). Selective ignorance and agricultural research. Science Technology and Human Values, 38(3), 328-350.

172. Krimsky, S., \& Gillam, C. (2018). Roundup litigation discovery documents: implications for public health and journal ethics. Journal of Public Health Policy (Epub ahead of print).

173. McHenry, L. B. (2018). The Monsanto Papers: poisoning the scientific well. International Journal of Risk \& Safety in Medicine, 29(3-4), 193-205.

174. United States Department of Agriculture (2017). Farm production expenditures, 2016 summary. Washington, D.C.: United States Department of Agriculture. Table 3. U.S. Farm Production Expenses (\$ Billions) by Source, 2007-2012F. Retrieved from http://usda.mannlib.cornell.edu/ usda/nass/FarmProdEx/2010s/2017/FarmProdEx-08-03-2017.pdf

175. Willer, H., \& Lernoud, J. (2018). The world of organic agriculture. statistics and emerging trends 2018. Bonn: Research Institute of Organic Agriculture (FiBL), Frick, and IFOAM - Organics International. Retrieved from http:// www.organic-world.net/yearbook/yearbook-2018.html 